\title{
The occupational structure of further and higher education in Ireland and the Netherlands
}

Citation for published version (APA):

Borghans, L., Smits, W., \& Hughes, G. R. (1997). The occupational structure of further and higher education in Ireland and the Netherlands. Researchcentrum voor Onderwijs en Arbeidsmarkt, Faculteit der Economische Wetenschappen. ROA Research Memoranda No. 3E https://doi.org/10.26481/umaror.199703E

Document status and date:

Published: 01/01/1997

DOI:

10.26481/umaror.199703E

Document Version:

Publisher's PDF, also known as Version of record

\section{Please check the document version of this publication:}

- A submitted manuscript is the version of the article upon submission and before peer-review. There can be important differences between the submitted version and the official published version of record.

People interested in the research are advised to contact the author for the final version of the publication, or visit the DOI to the publisher's website.

- The final author version and the galley proof are versions of the publication after peer review.

- The final published version features the final layout of the paper including the volume, issue and page numbers.

Link to publication

\footnotetext{
General rights rights.

- You may freely distribute the URL identifying the publication in the public portal. please follow below link for the End User Agreement:

www.umlib.nl/taverne-license

Take down policy

If you believe that this document breaches copyright please contact us at:

repository@maastrichtuniversity.nl

providing details and we will investigate your claim.
}

Copyright and moral rights for the publications made accessible in the public portal are retained by the authors and/or other copyright owners and it is a condition of accessing publications that users recognise and abide by the legal requirements associated with these

- Users may download and print one copy of any publication from the public portal for the purpose of private study or research.

- You may not further distribute the material or use it for any profit-making activity or commercial gain

If the publication is distributed under the terms of Article $25 \mathrm{fa}$ of the Dutch Copyright Act, indicated by the "Taverne" license above, 


\title{
The Occupational Structure of Further and Higher Education in Ireland and the Netherlands
}

\author{
ROA-RM-1997/3E \\ Lex Borghans*, Gerard Hughes, ${ }^{* *}$ and Wendy Smits* \\ * Research Centre for Education and the Labour Market (ROA) \\ PO-Box 616, 6200 MD Maastricht, The Netherlands \\ ${ }^{* *}$ Economic and Social Research Institute (ESRI) \\ 4 Burlington Road, Dublin 4, Ireland
}

Research Centre for Education and the Labour Market

Faculty of Economics and Business Administration

Maastricht University

Maastricht, December 1997 
ISBN 90-5321-226-4

SEC98007/LB 


\section{Contents}

\section{Page}

Acknowledgement

Abstract

iii

1 Introduction

2 Structure of Education in Ireland and the Netherlands

3 Construction of Common Occupational Classification

4 Occupational Structure of Employment in Ireland and the Netherlands

5 Measuring switching opportunities and educational similarities

6 The results

7 Conclusions

References

Appendix 1 Common occupational classification

Appendix 2 Some tables of similarities between levels

Appendix 3 Similarities between Dutch and Irish types of education 


\section{Acknowledgement}

This paper is the result of a comparative study of the Irish and the Dutch educational system, by the Economic and Social Research Institute (ESRI) in Dublin, Ireland and the Research Centre for Education and the Labour Market (ROA), Maastricht, the Netherlands. The project has been commissioned by Cedefop in the context of the Ciretoq-network 


\begin{abstract}
Although most types of education give access to a range of occupations, the educational background determines to a large extent the labour market possibilities of a worker. However, since educational systems vary widely between different countries, there is a question about the specific role of each type of education in a country and the influence of the structure of the educational system as a whole on the relationship between education and the labour market. In this paper a comparison of the occupational structure of further and higher education in Ireland and the Netherlands is made. This comparison is based on a common occupational classification, which provides the possibility of measuring the extent of the occupational domains of types of education and the overlap in occupational domain of different types of education within each country and between both countries.
\end{abstract}

The extent of the occupational domain and the similarities within a country provide information about aspects of the occupational structure of higher education in both countries, while the similarities between types of education in both countries make it possible to determine in a simple way the mutual position of types of education in the two countries.

It is shown in the paper that since the Irish education system is more generally oriented than the Dutch system, Ireland has a broader occupational domain for similar types of further and higher education, on average, than the Netherlands. In addition the occupational domains for academics and technicians in Ireland have more overlap between different fields of study than in the Netherlands. Furthermore, despite the fact that the fraction of higher educated people in the Netherlands considerably exceeds the fraction in Ireland - which might result in some qualifications inflation - some types of education in Ireland, such as engineering and agricultural science, at higher levels seem to be closer to the Dutch intermediate vocational level than to the higher level. 


\section{Introduction}

The field of study is an important determinant of the position one gets on the labour market. The employment of people with a certain educational background is in most cases concentrated in specific occupations. Most types of education therefore have a limited occupational domain. On the other hand labour force statistics show that there is no exclusive relationship between education and occupation. This means that in most occupations people with different educational backgrounds are employed.

In order to compare educational systems of different countries it is, therefore, interesting to focus on the occupational domain in which people with a certain educational background are employed. Borghans (1992) introduces a similarity index which measures the overlap of the occupational domain of two types of education. In this paper this measure is used to compare the occupational structure of higher education in Ireland and the Netherlands. For this purpose a common occupational classification is developed. The similarities between types of education based on this common classification provide an instrument for two comparisons.

First, the occupational domain of Irish types of education can be compared with the occupational domain of Dutch education. This provides a tool to determine which fields and levels of study are close to each other in both countries, without an investigation of specific elements of the curriculum. Based on the assumption that types of education can be compared by looking at the similarity of the occupations, a matching can be made between types of education in different countries, in a statistically simple way. This approach can also be used within a country to indicate switching opportunities between occupations and to identify competing types of education in the labour market.

Second, a similarity index can be used to investigate the overlap on the labour market of different types of education within one country. This provides information about the structure of the educational system with regard to the labour market. Besides a direct comparison of the types of education in Ireland and the Netherlands, therefore, a comparison of the structure of the two educational systems can also be made, thus contributing to the debate on the merits of providing skills for life through general education or skills for the labour market through vocational education. The Irish educational system is mainly focussed on general skills, while the Dutch educational systems is mainly focussed on vocational skills.

This overlap of occupational domains of different types of education is an important feature of the structure of the labour market. It provides substitution possibilities and, therefore, flexibility with respect to the allocation of workers over occupations. From the point of view of the individual a field of study which gives access to more than one occupation has advantages. A balance has to be found between productivity and flexibility. If a worker is trained for only one profession opportunities depend too much on developments relating to 
this occupation. If, on the other hand, a type of education aims at a very broad occupational domain, students will not get enough skills and knowledge to function well in jobs which require specific training.

Borghans (1992) and Borghans, De Grip and Heijke (1996) provide a picture of the occupational structure of types of education in the Netherlands based on a similarity index. It shows the overlaps in occupational domains of the types of education distinguished in the Dutch educational system. The labour market opportunities are, of course, very much influenced by the institutional structure of the educational system. With increasing mobility of labour in Europe information for different countries on occupational switching opportunities for each type of education would help to ensure a better match between the demand and supply of labour by identifying, on the supply side, the extent of the occupational domains in which those with a particular educational background can find work and, on the demand side, the flexibility which employers have to recruit workers with different educational backgrounds for a specific occupation. Hence, it is important to put the analysis of occupational domains in an international context.

The analyses are based on the Irish Census of Population and the Dutch Labour Force Survey. The most recent Irish Census which contains information concerning the field of study for further and higher educated is the census of 1986. To match Irish and Dutch data as closely as possible, Dutch data for 1985 have been used. Although the types of education distinguished are different in both countries, a comparison is possible if a standard occupational classification is used. The educational systems are therefore compared by using similarities in the occupational structure.

The structure of this paper is as follows. Section 2 starts with a short description of both the Irish and the Dutch educational system. Section 3 explains the way the common occupational classification is produced. Based on this common classification section 4 gives an empirical description of the occupational structure of the labour market, and the role of higher education in it, in the two countries. Section 5 continues by introducing the two indexes which have been used for the comparisons, i.e. the index of the occupational domain and the similarity index. By using these indexes in section 6 the educational systems of Ireland and the Netherlands are compared. First, this section presents a comparison of some structural characteristics of the labour market in the two countries and second, it provides the results of the matching of Irish and Dutch types of education. Finally, in section 6 some conclusions are drawn, both on the usefulness of the method applied and on the results of this international comparison.

\section{Structure of Education in Ireland and the Netherlands}

Unlike the Labour Force Survey for the Netherlands the Irish Census of Population does not contain information on educational attainments by field of study for first and second 
level education. For this reason the comparison of the occupational structure of education is confined to scientific and technological qualifications which are awarded for successfully completing courses of study after second level. In order to assess the interaction between such educational qualifications and occupational choice it is necessary to have an overview of the structure of education in both countries at all levels. Figure 1 provides a bird's-eye view of how the different levels of education are structured in Ireland and the Netherlands.

\section{The Irish system}

Primary level education in Ireland lasts for eight years, including two years in junior and senior infants class, from age four to age twelve. Secondary education is divided into a junior and senior cycle. The junior cycle lasts for three years from age twelve to fifteen. At the end of the junior cycle the junior certificate examination is taken. The results of this examination influence students choice of school for the senior cycle of secondary education. In the senior cycle general and vocational education streams are provided. The vocational stream provides courses for apprentices which require attendance at school for two to three days per week and for students who wish to study practical as well as academic courses for the Leaving Certificate examination. Both the general and vocational streams take two years to complete. At the end of the senior cycle all students take the Leaving Certificate examination.

The results of this examination determine whether the student will go on to third level education in a University or Regional Technical College, to a Vocational Preparation and Training (VPT) or other course at Post-Leaving Certificate (PLC) level, or into the labour force. Since there is an excess demand for places at third level entry is rationed by means of points based on performance in the Leaving Certificate examination. Professional courses such as medicine and engineering require very high points to secure a place in university. Other courses such as business and computer studies also require quite high points. A range of technologicial and vocational courses for technicians is provided by the Regional Technical Colleges. Entry into these colleges is also rationed. Applications for university or Regional Technical College are handled by the Central Applications Office. Applicants are requested to rank ten course choices in order of preference. The points which they are awarded in the Leaving Certificate examination determines which preference they get. Three levels of technicians are distinguished. Courses for lower technicians (1 year) and technicians (2 years) can be regarded as further education, while higher technicians receive a diploma that is comparable to primary degree at university.

With the exception of a few courses such as medicine, dentistry, and teaching labour market employment prospects do not directly influence the provision of places in the universities or the Regional Technical Colleges. About half of the school leaving cohort each year is awarded a place at third level and a further 20 per cent go on to Post-Leaving Certificate courses. 
Figure 1

Structure of education in Ireland and the Netherlands

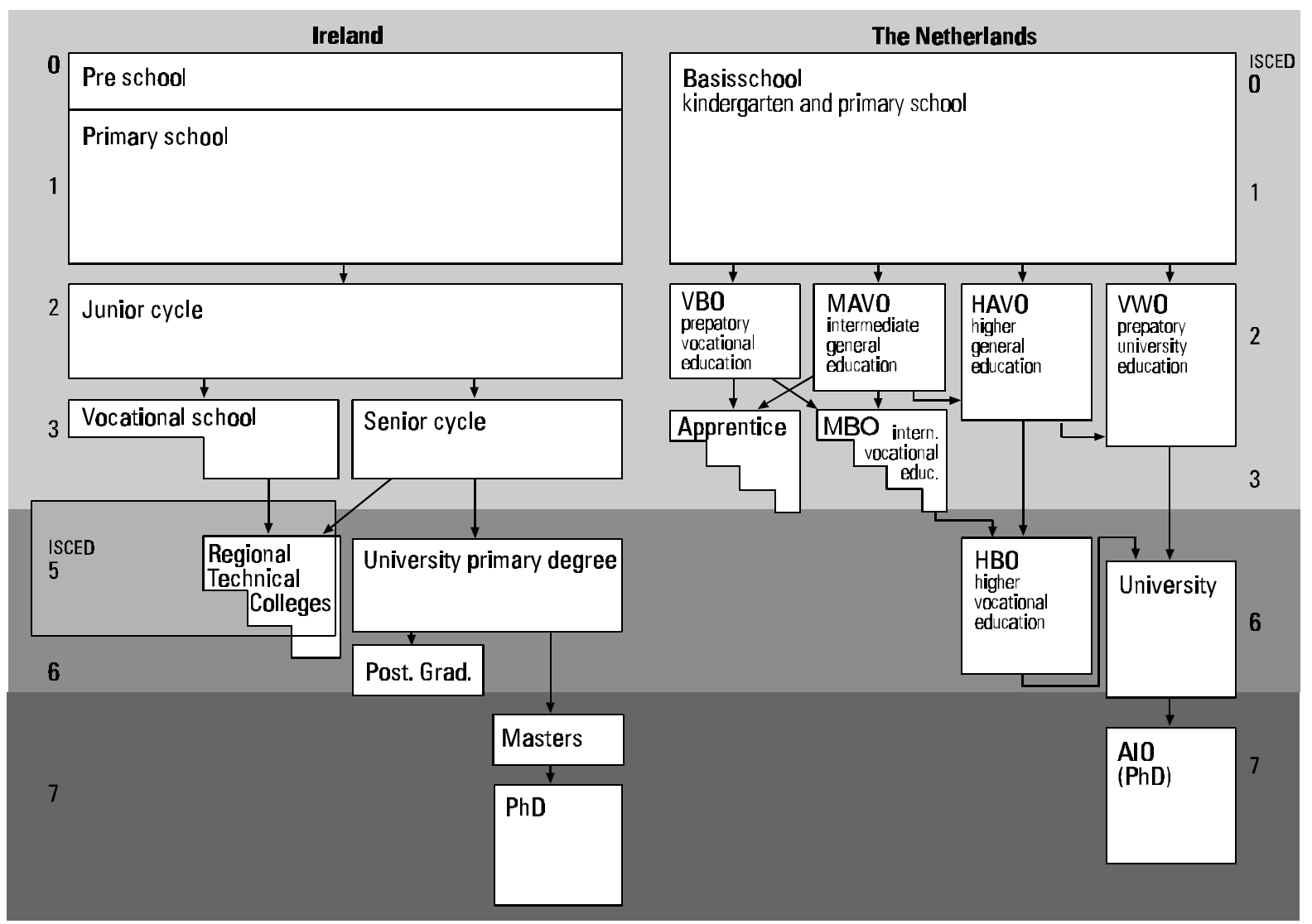

The Dutch system

In the Dutch educational system kindergarden and primary school were combined ten years ago into one primary school (basisschool) for children from 4 until 12. This is therefore equivalent to the Irish primary level. After primary school, children have to choose between three levels of general education and prepatory vocational education (VBO). The highest level of general education (VWO) takes 6 years and prepares children for the university. In practice however almost half of those in VWO transfer to higher vocational education (HBO). HAVO provides general education at a lower level, and therefore gives no access to university, but only to higher vocational education. Also for this type of education, which takes 5 years, many school-leavers continue their education at a lower level than formally intended, namely intermediate vocational education (MBO). MAVO is the lowest level of general education. It takes 4 years and provides entrance to intermediate vocational education. VBO, the vocational track, used to be the lowest vocational level. Five years ago the name was changed from lower vocational education to prepatory vocational education, as it was generally recognized that this level did not suffice anymore as an adequate entrance level for the labour market in the Netherlands. Students are therefore encouraged to continue their education in intermediate vocational education or in the apprenticeship system. 
At third level there is, as mentioned earlier, higher vocational education and university education. Both take 4 years, but university is of course more oriented towards academic skills, while higher vocational education prepares students directly for a certain occupation. Access to both university and higher vocational education is open in principle to everyone who has his VWO (for both university and higher vocational education) or HAVO degree (only for higher vocational education). Rationing of places is rare. Only in a few cases capacity contraints or labour market problems might lead to rationing, based on a weighted lottery, in which the weight depends on the points at VWO or HAVO. Only for medicine does this numerus fixus appear to be permanent. Both at university and higher vocational education there is only one level of qualification. The only university level qualification is called doctorandus, which is equivalent to a Masters degree. The qualification at HVE level is called a HBO-diploma. After the university degree students can continue their academic development by writing a thesis. They are however, in that case, not considered as students, but as employees. These specific jobs are indicated by the term AIO. For that reason the PhD-degree is not separately classified in the educational classication.

\section{Main differences}

The main differences between the Irish and the Dutch educational system arise from the focus on vocational education in the Netherlands and on general education in Ireland. In Ireland students follow largely uniform tracks leading to standardization of their qualifications. In addition, they have a number of opportunities during their education when they can decide whether to continue their studies. In the Netherlands there is strong stratification of education - primarily between levels and later on between fields of study. This limits standardization and forces students to make early decisions which have consequences for both the length of their education and their field of specialization. Consequently, it might be expected that the vocational orientation of Dutch education will result in smaller occupational domains than the academic orientation of Irish education, and that there will be less overlap in the Netherlands than in Ireland in the occupational domains of different types of education. The main differences between the Irish and Dutch educational systems are brought out sharply in a typology developed by Müller, Shavit and Ucen (1996) using information supplied by Breen and Whelan (1995) for Ireland and by De Graaf and Ultee (1995) for the Netherlands. The classification of educational systems used by Müller et al., is shown in Table 1.

Müller et al., (1996) hypothesise that the weakest effects of education on occupational outcomes should be in the countries in cell (1), the strongest effects should be in the countries in cell (6). Countries in cell (4) should be closer to the weak end and those in cells (3) and (5) should be closer to the strong end. Thus their hypotheses suggest that the relationship between education and occupational outcomes should be weaker in Ireland than in the Netherlands. In our terms this would mean that the extent of occupational domains should be greater in Ireland than in the Netherlands and also that the overlap for types of education is expected to be larger for Ireland than the Netherlands. 
Table 1

Thirteen countries by level of standardization, stratification and prevalence of specific vocational education

\begin{tabular}{|c|c|c|c|}
\hline Standardization & Low & $\begin{array}{l}\text { Stratification } \\
\text { Medium }\end{array}$ & High \\
\hline Low & $\begin{array}{l}\text { (1) } \\
\text { Australia * } \\
\text { Japan } \\
\text { Great Britain* } \\
\text { United States } \\
\text { (4) } \\
\text { Ireland } \\
\text { Sweden* }\end{array}$ & $\begin{array}{l}(5) \\
\text { Finland* } \\
\text { Italy* }^{*} \\
\text { Israel* } \\
\text { Taiwan* }\end{array}$ & $\begin{array}{l}\text { (3) } \\
\text { Netherlands }{ }^{\star *} \\
\text { (6) } \\
\text { Germany }{ }^{* *} \\
\text { Switzerland** }\end{array}$ \\
\hline
\end{tabular}

${ }^{*}$ Intermediate vocational specificity ** High vocational specificity

Source: Müller, Shavit and Ucen (1996)

\section{Construction of Common Occupational Classification}

Both the Irish and Dutch occupational classifications have been strongly influenced by ISCO 68 - the International Standard Classification of Occupations which was published in $1968^{1}$. This is a basic tool for organising occupational information for international comparisons. The first international classification was developed over a number of years by the International Labour Organisation assisted by the International Conference of Labour Statisticians, and published in 1958. This classification was subsequently revised by the ILO. A draft classification was submitted to the Eleventh International Conference of Labour Statisticans in 1966 and following some improvements the Conference adopted the list of major, minor and unit groups of occupations. The revised classification was published by the ILO as ISCO 68 in 1968.

In addition to providing a basis for international comparisons ISCO 68 has a second objective. This, as the ILO (1969, p. iii) points out "is to provide an international standard classification system which countries may use in developing their national occupational classifications, or in revising their existing classifications, with the aim of achieving convertibility to the international system." ISCO 68 contains 264 unit groups, the Irish Census uses 199 unit groups and the Dutch Labour Force Survey 310. These differences

1. Recently Statistics Netherlands adapted a new occupational classification which has a completely different structure. The 1985 data, used in this paper, are however still classified according to this ISCO-oriented classification. 
in the number of unit groups arise because it was not intended that countries would adopt ISCO 68 for direct use. Instead it was envisaged that in developing their national classification countries would ensure that occupational groups corresponding as closely as possible to the ISCO classification could be identified.

It is important in using a standard international classification of occupations that it should not confuse "formal skill, job title, occupational status and functional and industrial affiliation in delimiting the occupations" as the $\operatorname{OECD}(1971$, p. 12) points out. Those responsible for developing ISCO claim that the basic occupations at the 5-digit level, of which there were over 1,300 in ISCO 58, do represent the functions performed in each occupation. Parnes, cited in OECD (1971, p. 12) accepts this claim and notes that "since it (ISCO) includes detailed occupational definitions, it allows occupations to be classified on the basis of their functional content, thus minimising the difficulties that arise out of differences in the meaning of national occupational titles".

Given the international classification which underpins both the Irish and Dutch occupational data it is feasible to develop a common occupational classification for the two countries. The common classification was constructed as follows:

1. An initial match was made between the classifications for the two countries on the basis of the occupational titles. Occupations in Ireland and the Netherlands with similar titles were allocated to the same group. This procedure produced 186 groups including a residual group containing occupations with dissimilar titles. The residual group contained eight occupations for Ireland and 23 for the Netherlands. The first mapping therefore produced a relatively small number of occupations for which matches were not immediately evident.

2. The coding manuals which are used to classify specific occupations in Ireland and the Netherlands, which number more than 1,500 in both cases, were examined to ensure that essentially the same occupations were included in unit groups with similar titles in the two countries. Where this was the case an ESRI-ROA ${ }^{2}$ code was assigned to the group. Where there was a significant difference between the two countries in the occupational content of the unit groups the coding manuals were used to identify unit groups with dissimilar names which contained predominantly the same job categories. The second mapping produced 157 ESRI-ROA unit groups covering all occupations in Ireland and the Netherlands.

3. The percentage of the labour force employed in each of the ESRI-ROA groups was calculated and the ratio of the percentage for Ireland to that for the Netherlands was derived. Occupational groups for which this ratio was significantly greater or less than

2. ESRI stands for the Economic and Social Research Institute in Ireland and ROA for the Research Centre for Education and the Labour Market in the Netherlands. 
one were identified. The job categories included in each group in each country were again examined to see if the discrepancy could reasonably be attributed to a genuine difference in employment structure in the two countries or if it appeared to be a classification problem. In 8 of the 157 cases it appeared that the problem was due to a misclassification. It was evident in these cases that the problem could be dealt with by including the misclassified group with another group. This resulted in a reduction in the number of ESRI-ROA codes from 157 to 153.

4. The 153 ESRI-ROA unit groups were then adopted as the common classification for Ireland and the Netherlands. The common classification is given in Appendix 1.

\section{Occupational Structure of Employment in Ireland and the Netherlands}

To start the comparison between Ireland and the Netherlands in this section the occupational distribution of employment and the participation of higher educated in each country are investigated. To summarize the results the ISCO 68 major group classification is used together with an extra group for labourers.

Table 2

Percentage distribution of those at work in Ireland in 1986 and in the Netherlands in 1985 by major ISCO 68 occupational group and the ratio of employment in Ireland to employment in the Netherlands by major group

Major group $\quad$ Ireland Netherlands. Irl./ Neth.

0/1: Prof., technical and related workers

2: Administrative and managerial workers

16.1

0.9

14.5

10.9

11.7

14.8

5.6

9.1

10.6

5.7

100.0
22.4

0.4

18.3

10.3

12.1

4.6

5.2

8.6

15.3

2.8

100.0
0.7

2.3

0.8

1.1

1.0

3.2

1.1

1.1

0.7

2.0

1.0

The ratios of the percentage employed in each major occupational group in Ireland to the percentage employed in the Netherlands are shown in Table 2. There are proportionately three times as many people working in agricultural occupations in Ireland as in the Netherlands, twice as many administrative and managerial workers and labourers, around the same proportion of sales, service, production, and craft workers, and 20 to 30 per cent less clerical, professional and printing, building, and transport workers. Explanations can be 
given for these differences in the cases of agricultural and labouring occupations. Explanations in the cases of the remaining occupational groups must await further research into the relationships between industrial structure and occupational composition.

In Ireland nearly 15 per cent of the workforce is engaged in agricultural and related occupations whereas in the Netherlands less than 5 per cent of the workforce is in such occupations. The greater concentration in agricultural occupations in Ireland is, of course, a reflection of real differences in endowments and product specialisation in the two countries.

The concentration in agricultural occupations in Ireland might affect representation in the remaining occupational groups. However, estimation of the occupational distribution excluding agricultural occupations does not substantially alter the relationships between the percentages employed in the major groups. Hence, the distribution including agricultural occupations will be used to make comparisons between the two countries.

The differences in the percentage employed in group 2, administrative and managerial workers, and group 10, labourers, stand out as there are more than twice as many employed in these groups in Ireland relative to its population as there are in the Netherlands. Group 2 has a comparatively narrow focus as it consists of "occupations primarily concerned with the formulation of policy or laws and public regulations (legislation) and interpretation of government policy", as the ILO (1968, p. 11) points out. The greater number of legislators and administrators in Ireland relative to the Netherlands may be due to economies of scale in administration or to differences in the electoral system in the two countries.

Ireland also has more than twice as many labourers as the Netherlands - excluding agricultural labourers who are included in group 6. The labourers group covers a heterogenous range of jobs whose common characteristic is that they require physical labour to do them. Examples of the kind of jobs included in this group are: park cleaner, street sweeper, gravedigger, hod carrier, refuse collector, factory cleaner, and vechicle washer. One reason for the larger percentage of labourers in Ireland than in the Netherlands is that there is vocational preparation and training for digging and cleaning jobs in the Netherlands and one of its objectives is to ensure that the skill content of such jobs is increased. In Ireland there is no vocational preparation or training for labouring jobs.

An overview of individual occupations in which there are far more or less people employed in Ireland than in the Netherlands is given in Table 3. This table contains information on 10 individual occupations for which the ratio of employment in Ireland relative to employment in the Netherlands is highest and 10 occupations in which this ratio is lowest. The emphasis on the extreme differences between the two countries may pinpoint weaknesses of the common classification since mismatches in the classification may show up as large quantitative differences. 
Table 3

Ten occupations in which employment is far more or less prevalent in Ireland than in the Netherlands

ESRI-ROA

Occ. code Occupation

Ireland

Nether- Irl./

lands Neth.

Occupations which are more prevalent in Ireland

32 Woodware makers

$\begin{array}{lll}0.001 & 0.000 \quad \infty\end{array}$

46 Sugar processors

$0.161 \quad 0.003$

58.0

102 Livestock (non-farm) workers

0.071

0.001

49.7

119 Labourers and unskilled workers n.e.s.

$3.583 \quad 0.181$

19.8

40 Occupations related to spinning, weaving, knitting and dyeing 16.6

39 Knitters

0.223

0.407

0.024

10 Miners

0.105

0.017

13.0

127 Chartered, hydrographic and quantity surveyors

0.121

0.010

10.4

143 Professed clergymen and nuns

0.162

0.016

7.6

120 Legislative officials and government administrators

0.523

1.169

6.9

0.086

6.1

ESRI-ROA

Occ. code Occupation

Ireland

Nether-

Neth./

lands

|rl.

Occupations which are less prevalent in Ireland

86 Ships' officers

25 Metal coaters, platers, benders, etc.

129 Professional workers n.e.s.

52 Makers of paper and paperboard

69 Commercial designers

56 Metal casters, moulders, setters, drawers etc.

132 Life sciences technicians

26 Technical inspectors

130 Bacteriologists

139 Mathematicians, statisticians and actuaries

$\begin{array}{llr}0.049 & 0.218 & 4.4 \\ 0.012 & 0.056 & 4.9 \\ 0.169 & 0.970 & 5.7 \\ 0.025 & 0.151 & 6.0 \\ 0.058 & 0.350 & 6.1 \\ 0.035 & 0.230 & 6.6 \\ 0.052 & 0.467 & 8.9 \\ 0.037 & 0.360 & 9.6 \\ 0.004 & 0.052 & 13.2 \\ 0.019 & 0.475 & 25.6\end{array}$

The percentage of higher educated people in major occupational groups in the two countries is shown in Table 4. People with scientific and technological qualifications at third level are classified as higher educated for the purposes of this table. In Ireland the classification includes people with lower technician, technician, higher technician, primary degree, and post-graduate non-degree and degree qualifications. For the Netherlands it includes people with a university degree or higher vocational education.

Table 4

Percentage of persons in major occupational groups with higher education in Ireland and the Netherlands.

Major group

Ireland Nether- Irl./ Neth. 
lands

0/1: Prof., technical and related workers

2: $\quad$ Administrative and managerial workers

3: $\quad$ Clerical and related workers

4: $\quad$ Sales workers

5: $\quad$ Service workers

6: $\quad$ Agricultural and related workers

7: $\quad$ Production and related workers

8: $\quad$ Craft and skilled operatives

9: $\quad$ Printing, building, and transport workers

10: Labourers
39.9

12.2

2.1

2.8

2.2

12.4

1.4

3.5

1.4

1.2

11.0
63.5

$\begin{array}{rr}9.9 & 0.21 \\ 11.1 & 0.25\end{array}$

$\begin{array}{ll}7.8 & 0.28\end{array}$

$9.0 \quad 1.37$

$2.7 \quad 0.52$

$1.9 \quad 1.84$

$5.9 \quad 0.24$

$4.8 \quad 0.25$

$18.9 \quad 0.58$

People at work in the Netherlands are far more likely than people at work in Ireland to have higher level qualifications. Only 11 per cent of the workforce in Ireland have such qualifications whereas in the Netherlands the figure is nearly 19 per cent. There are only two major occupational groups, agricultural and craft, where the percentage with a higher level education is greater in Ireland than in the Netherlands. For all the remaining groups the percentage with higher education is significantly less than in the Netherlands. Thus, the number of administrative and managerial, clerical, sales, service, printing, and labouring workers in Ireland who have higer education is only 20 to 30 per cent of the number in the Netherlands when differences in the total number at work are taken into account.

Even for the professional, technical and related workers group, for which higher education is a prerequisite for many occupations, the percentage with higher education is significantly less in Ireland, 40 per cent, than in the Netherlands, 60 per cent. The ten individual occupations which have the highest and lowest percentage of people with higher education in Ireland relative to the Netherlands are shown in Table 5. Since the ratio between both fractions can become extremely large if the denominator approaches zero, occupations are only included in the table when the numerator is at least $2.5 \%$. This guarantees that the results are not caused by sampling errors.

There are some remarable results in this table. The fraction of higher educated workers in 'pharmacists and dispensers' is low in the Netherlands, because in this occupational group people are included who prepare and sell medicines in Dutch pharmacies. In contrast with the person in charge of the pharmacy these people have an intermediate vocational qualification. Furthermore in the Netherlands there are more higher educated nurses than in Ireland. This is due to the fact that the highest level of nursing qualifications is not classified at the higher level in Ireland, whereas it is in the Netherlands. The large fraction of higher educated clergymen and nuns in the Netherlands arises from the fact that the only religious profession which is left is the priesthood, and the great majority of priests in the Netherlands have a university qualification. 
Table 5

Ten occupations in which the percentage of higher educated people is far more or less prevalent in Ireland than in the Netherlands

ESRI-ROA Occupation

Occ. code

Ireland

Nether-

Irl./

lands Neth.

Occupations in which higher education is more prevalent in Ireland

$7 \quad$ Forestry and skilled forestry workers

102 Livestock (non-farm) workers

38 Bleachers, dyers and finishers

14 Radio and television mechanics

135 Pharmacists and dispensers

6 Other agricultural workers

17 Fitters and other mechanics

11 Telephone installers

4 Gardeners - skilled

5 Gardeners - unskilled

$\begin{array}{rrr}9.5 & 0.0 & \infty \\ 3.1 & 0.0 & \infty \\ 2.9 & 0.0 & \infty \\ 21.8 & 0.7 & 30.4 \\ 87.4 & 8.0 & 10.9 \\ 14.7 & 1.5 & 9.9 \\ 9.7 & 1.5 & 6.5 \\ 5.7 & 1.7 & 3.4 \\ 12.0 & 3.7 & 3.3 \\ 3.3 & 1.1 & 3.1\end{array}$

Ireland

Nether-

Neth./

lands Ireland

Occupations in which higher education is less prevalent in Ireland

$\begin{array}{llrrr}141 & \text { accountants } & 4.7 & 66.8 & 14.0 \\ 143 & \text { professed clergymen and nuns } & 6.4 & 95.7 & 15.0 \\ 106 & \text { chefs and cooks } & 0.3 & 4.2 & 15.9 \\ 39 & \text { knitters } & 0.4 & 7.1 & 17.8 \\ 80 & \text { sailors: skilled } & 0.9 & 17.7 & 19.7 \\ 147 & \text { painters, sculptors and commercial artists } & 3.1 & 62.2 & 20.1 \\ 89 & \text { typists } & 0.8 & 19.7 & 24.6 \\ 137 & \text { nurses } & 0.6 & 15.1 & 25.2 \\ 100 & \text { street vendors } & 0.4 & 16.9 & 42.2 \\ 52 & \text { makers of paper and paperboard } & 0.0 & 7.2 & \infty\end{array}$

\section{Measuring switching opportunities and educational similarities}

The information about the occupational structure of higher education based on the common classification can be used to compare the labour market position of types of education in both countries and the educational structure as a whole. In order to investigate the extent of the occupational domains and the overlaps in the occupational domains between types of education a number of different measures is needed. In this paper the extent of the educational domain is measured by an index which is closely connected to the indicator for switching opportunities introduced by Warnken (1986), and De Grip and Heijke (1988). The overlap in the occupational domain is measured by the similarity index introduced in Borghans (1992). In this section both measures will be explained while attention will also be paid to the way in which these indices can give additional information 
about the developments in the occupational structure of types of education.

The extent of the occupational domain

As mentioned, although sometimes vocational education is focussed on a specific job, in actual practice people with a certain educational background are employed in a range of occupations.

Following Warnken (1986) the extent of an occupational domain can be measured by the Gini-Hirschman-index. This index is based on the probability that two people with the same educational background are in the same occupational group. If $f_{i j}$ reflects the fraction of people with educational background $i$ in occupation $j$ (and thus $\sum_{j} f_{i j}=1$ ) then this probability equals:

$P_{i}=\sum_{j} f_{i j}^{2}$

This probability equals 1 if everyone is in the same occupational group, while it equals $1 / m$ - where $m$ denotes the number of occupational groups - if all workers are spread equally over all occupations. Based on this probability the following index of the extent of the occupational domain can be calculated as:

$K_{i}=\frac{1}{P_{i}}$

This transformation has the property that if people with educational background $i$ are occupied in $n$ occupations, where in all these occupations the fraction equals $1 / n, K_{i}=n$. Therefore this index can be interpreted as the equivalent number of occupations of the occupational domain.

The first panel of figure 2 gives an example of this. It shows an imaginary type of education. The people in the work force with this educational background are spread equally over four different occupations. This implies that the probability that two people with the same educational background work in the same occupation equals 0.25 . There is a probability of $1 / 4 \times 1 / 4=1 / 16$ that both work in occupation 1 , and also a probability of $1 / 16$ that they both work in occupation 2, 3 or 4 . This implies that the meaure of the extent of the occupational domain equals $1 / 0.25=4$, i.e. the number of occupations involved.

Figure 2

Example of two occupational distributions (1) with a uniform spread and (2) with occupations of different importance, which both have an extent of the occupational domain of 4 

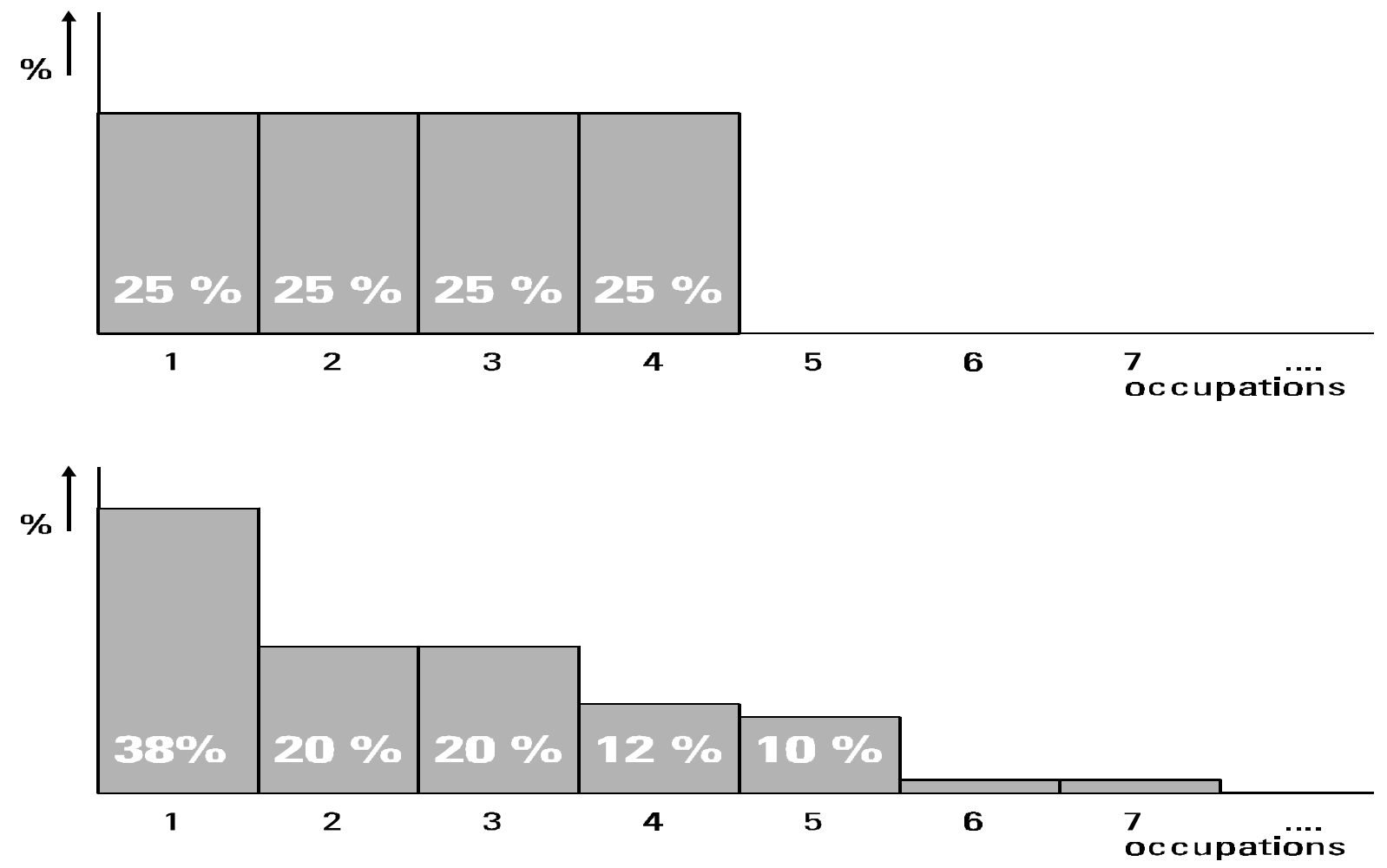

In practice, of course the occupational spread of a type of education will be less uniform than in this example. The second panel of figure 2 gives an example of this. By just counting the number of occupations people in the work force with this educational background are working in, the importance of the smaller occupations would be overemphasized. The index used, however, gives more weight to the larger occupations since the probability that two workers with the same educational background are in this occupation is larger. Therefore, although the example of the second panel of figure 2 is, on the one hand, more concentrated in some occupations and, on the other, hand more spread over other occupations, the extent of the occupational domain is also measured as 4.

\section{Overlap in occupational domains}

Besides the fact that most types of education have an occupational domain of more than one occupation, it will in general also be the case that within one occupation there will be people with a different educational background. Therefore, there is an overlap in the occupational domain of different types of education. To get an impression about the occupational switching opportunities and the degree of overlap between educational types a measure of dispersion and a measure of similarity are needed.

In the same way as measuring the probability that two people with the same educational background are in the same occupation, it is also possible to calculate the probability that two people with a different educational background are occupied in the same job: 
$P(i, i i)=\sum_{j} f_{i j} f_{i i j}$

This probability gives insight into the degree of overlap between the occupational domains of two types of education. The similarity measure (Borghans, 1992) equals this probability, relative to the probability that people with the same educational background are in the same occupation:

$\operatorname{Sim}(i, i i)=\frac{P(i, i i)}{\sqrt{P_{i} P_{i i}}}$

The similarity index equals 1 if $i$ and $i i$ have the same distribution over the occupations and equals 0 if there is no occupation in which both a worker with educational background $i$ and with background ii are employed ${ }^{3}$.

Figure 3 provides an example of this measure. It provides the occupational distribution of two types of education which both have an occupational domain of 4 . There are in this example two overlapping occupations. Therefore the probability that a worker with one educational background meets a worker with another educational background in the same occupation equals $1 / 4 \times 1 / 4+1 / 4 \times 1 / 4=1 / 8$. Since the probability that workers with the same educational background are in the same occupation equals $1 / 4$ for both types of education, the ratio between these probabilities equals 0.50 , i.e. the two types of education share $50 \%$ of their occupational domain.

As in the first example of the extent of the occupational domain, so too, in this example the distribution over occupations is more uniform than will be found in practice. The similaritymeasure takes care of the influence of larger and smaller jobs in a similar way. Furthermore, the example is also stylized since both types of education have an occupational domain of equal size.

Figure 3

Example of two types of education with an equally sized occupational domain, which has an overlap of $50 \%$

3. A major source of overlap in the educational domain is the occupation teacher. For example, many graduates from both arts and mathematics find work as teachers. This does, however, not imply that these types of education can be regarded as substitutes. For that reason, the similarity between types of education from the teacher occupation is only counted for people with the same field of study. 

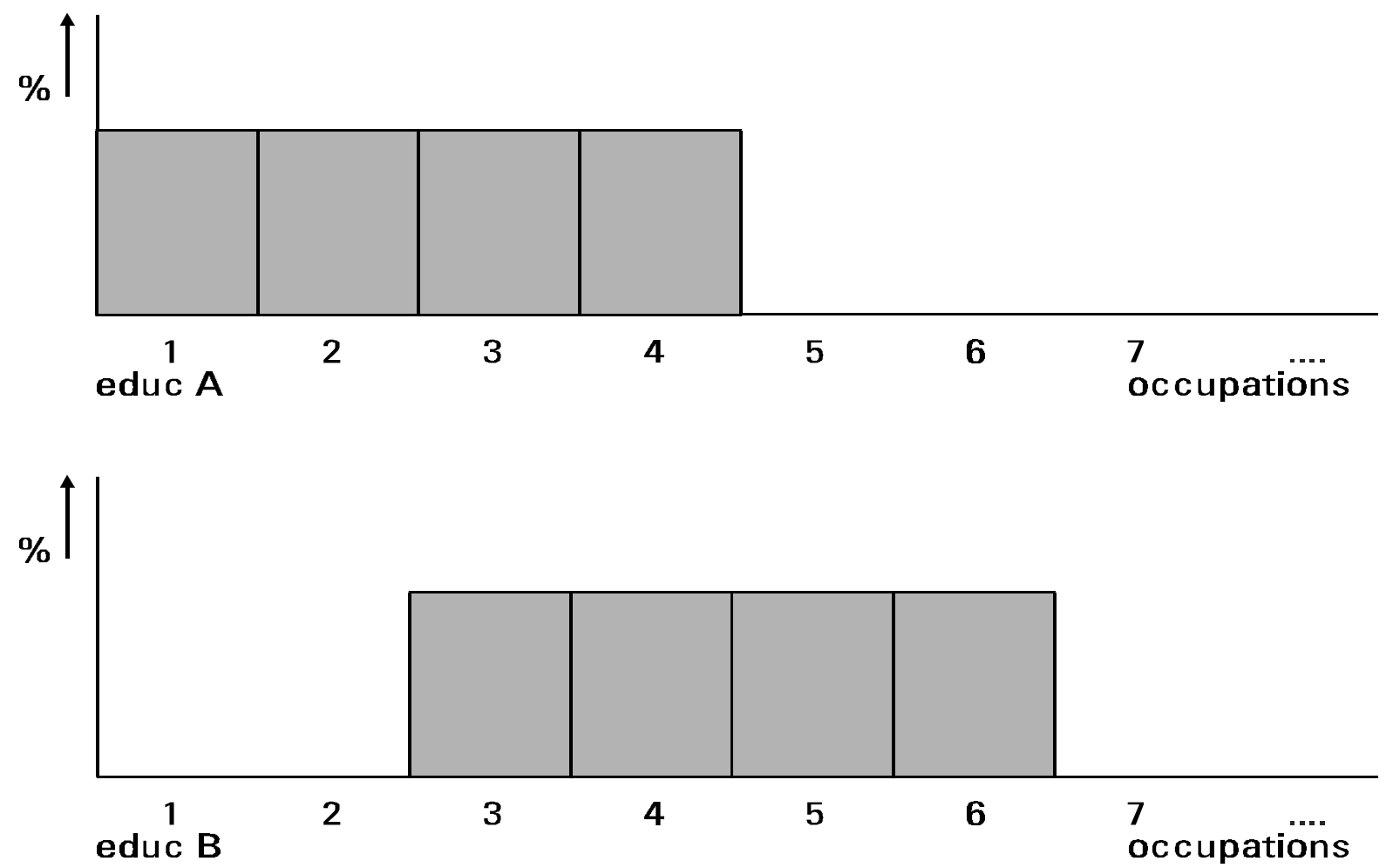

Figure 4 provides an example in which two types of education share two occupations, but in which the extent of the occupational domain equals 4 for one and eight for the other. The probability for overlap for workers with these educational backgrounds reduces to $1 / 16$, due to the larger spread of the second type of education. Comparing this probability to the extent of the occupational domain of the first type of education, would imply a similarity of 0.25 , while the similarity would be 0.50 if the second type of education is used as a reference. These outcomes reflect the fact that the first type of education overlaps 0.25 of the second, but the second overlaps half of the first occupational domain. The similarity measure compromises between these outcomes and equals 0.35 , i.e. the geometric mean of 0.50 and 0.25 .

Since a common occupational classification has been developed for both Irish and Dutch occupations, the similarity index can also be used to compare the occupational structure of types of education in both countries. Even if the types of education are not made comparable, the index will provide information about what types of education in both countries are close to each other. So the similarity measure provides an alternative to matching types of education by comparing curriculum elements

Figure 4

Example of two types of education with differences in the extent of the occupational domain 

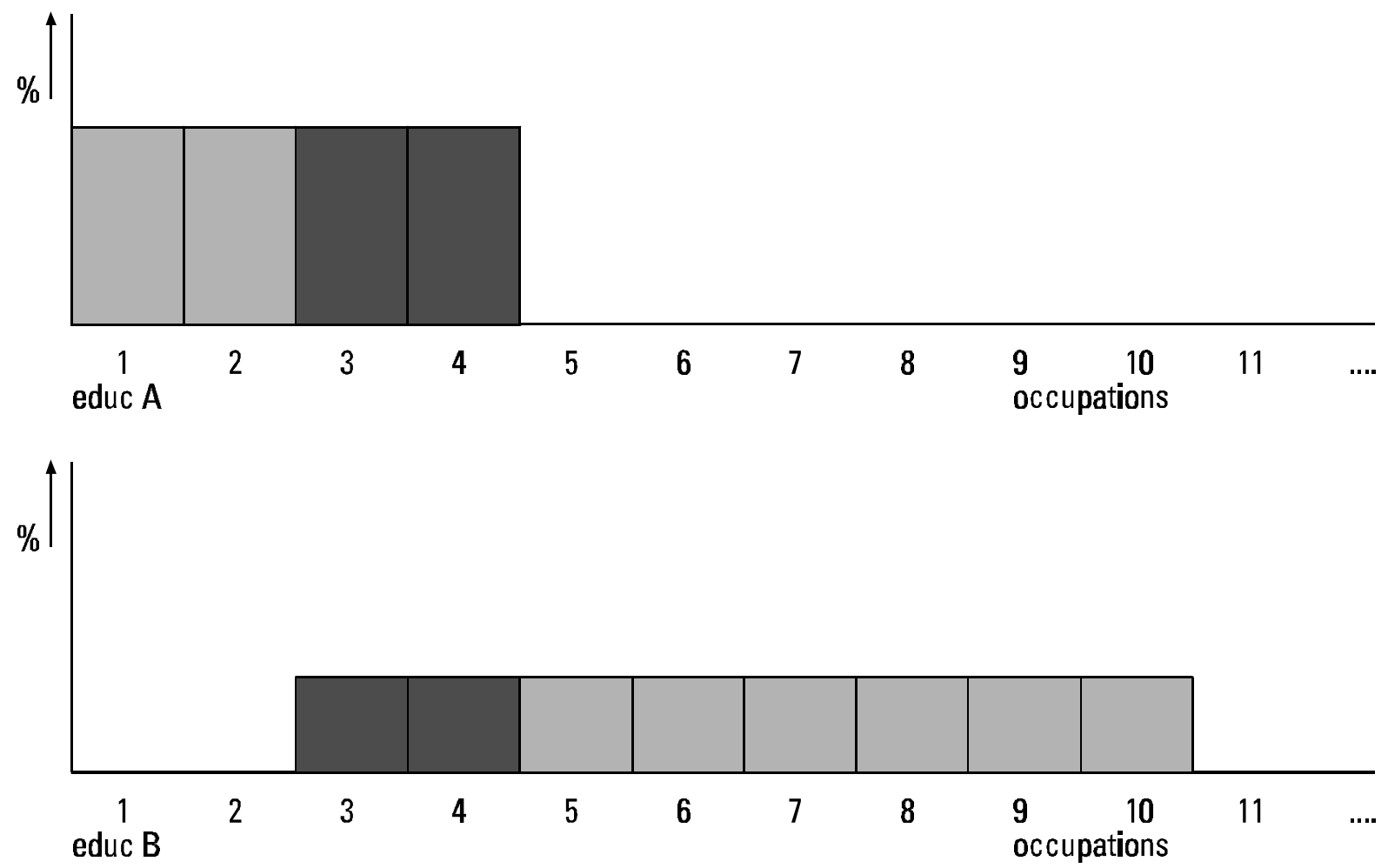

\section{The results}

In this section an overview is provided of the results of the comparative analyses. Three topics can be distinguished. First, attention will be paid to the extent of the occupational domain in both Ireland and the Netherlands. Second, the relationship between types of education within one country is investigated. Third, a comparison between the position of types of education in Ireland and the Netherlands is made. As an example most tables will focus on engineering. Furthermore, average figures for all fields of study are presented. The tables for other specific fields of study can be found in appendix 2 .

\section{The extent of the occupational domain}

First, table 6 provides information about the extent of the occupational domain for types of education in Ireland and the Netherlands. The figures are calculated for individual types of education, but the table presents averages per level. For the Netherlands three levels have been distinguished.

Table 6

The extent of the occupational domain

Ireland

Ph.D. 
Masters (M.A.)

Post grad. (P.G.)

Primary degree (P.Deg)

Higher technicians (High T.)

Technicians (T.)

Lower technicians (Low T.)

Netherlands

University education (UE)

Higher vocational education (HVE)

Intermediate vocational education (IVE)
6.9

6.5

4.4

8.3

7.4

10.3

4.3

5.0

14.8

The table shows that the Intermediate vocational level has on average the largest occupational domain. The extent of the occupational domain decreases with the level, although the difference between the intermediate and the higher vocational level is much larger than the difference between higher vocational and university education.

The figures for Ireland provide a slightly different picture. In Ireland the technicians have a broader domain than academics, as is the case in the Netherlands. The extent of the occupational domain for the three levels of technicians is larger than for the Dutch higher vocational level, while the extent of the occupational domain for Irish academics at all levels, except PhD's, is larger than for Dutch academics. Within the technician level lower technicians have the largest occupational domain. At university level masters have more occupational switching opportunities than those with primary degree. Post-graduate diploma's also increase the occupational domain, while PhD's appear to be very specialized.

\section{Similarities within a country}

The Gini-Hirschman indicator provides information about the extent of the occupational domain while the similarity-index gives information about the overlap in occupational domain between types of education. Table 7 provides figures for the overlap in occupational domain for engineering at three levels in the Netherlands. By definition the similarity of a type of education with itself equals 1 . Therefore the diagonal contains 1 's. The table shows that the similarity between engineering at University level and HVE level is rather high, while the similarity between HVE and IVE is much lower in engineering. As expected, it also shows greater similarity between HVE and IVE than between UE and IVE.

Table 7

Similarities between levels of education in engineering in the Netherlands

UE HVE IVE


Table 8 presents the same information for Ireland. As more levels are distinguished in the Irish situation, this table also contains more similarity-indices. Close observation however shows a major difference with the Dutch situation. In Ireland there is a large similarity between the different levels of engineering within the university and within the vocational track, but the similarity between the technicians and the academics is rather low. The only exception is formed by the post graduates. This group shows a similarity with both the other university levels and with the technicians. The explanation for this is that the additional courses followed by the post-graduates facilitates a transition from the academic occupations to the occupations technicians are generally found in.

Table 8

Similarities between levels of education in engineering in Ireland

Ph.D. M.A. P.G. P.Deg High T. T. Low T.

$\begin{array}{llllllll} & & & & & & \\ \text { Ph.D. } & 1.00 & 0.74 & 0.53 & 0.56 & 0.32 & 0.28 & 0.28 \\ \text { Masters } & 0.74 & 1.00 & 0.82 & 0.95 & 0.27 & 0.21 & 0.20 \\ \text { Post-grad. non-degree } & 0.53 & 0.82 & 1.00 & 0.82 & 0.64 & 0.63 & 0.59 \\ \text { Primary degree } & 0.56 & 0.95 & 0.82 & 1.00 & 0.23 & 0.18 & 0.16 \\ \text { Higher technician } & 0.32 & 0.27 & 0.64 & 0.23 & 1.00 & 0.93 & 0.87 \\ \text { Technician } & 0.28 & 0.21 & 0.63 & 0.18 & 0.93 & 1.00 & 0.96 \\ \text { Lower Technician } & 0.28 & 0.20 & 0.59 & 0.16 & 0.87 & 0.96 & 1.00\end{array}$

The structure of similarities that is found for engineering seems to be exemplary for most other Irish fields of study. Tables for other fields of study are included in appendix 2. In Ireland only social sciences and computer sciences are exceptional in the sense that for these sciences the similarities between academics and technicians is relatively high. For medical sciences the post-graduate diploma seems to have no effect upon the similarity in the occupational domain with the technicians. Here the overlap between the domain of the academics and the technicians is almost zero. Table 9 provides the average similarities between the levels (within a specific field of study). The picture these average similarities provides resembles the picture for engineering.

Table 9

Average similarities between levels of education in Ireland

Ph.D. M.A. P.G. P.Deg High T. T. Low T. 


$\begin{array}{llllllll}\text { Ph.D. } & 1.00 & 0.86 & 0.62 & 0.81 & 0.24 & 0.12 & 0.20 \\ \text { Masters } & 0.86 & 1.00 & 0.67 & 0.80 & 0.41 & 0.27 & 0.24 \\ \text { Post-grad. non-degree } & 0.62 & 0.67 & 1.00 & 0.81 & 0.65 & 0.57 & 0.49 \\ \text { Primary degree } & 0.81 & 0.80 & 0.81 & 1.00 & 0.44 & 0.27 & 0.28 \\ \text { Higher technician } & 0.24 & 0.41 & 0.65 & 0.44 & 1.00 & 0.68 & 0.79 \\ \text { Technician } & 0.12 & 0.27 & 0.57 & 0.27 & 0.68 & 1.00 & 0.67 \\ \text { Lower Technician } & 0.20 & 0.24 & 0.49 & 0.28 & 0.79 & 0.67 & 1.00\end{array}$

However, for the Dutch labour market the structure of engineering does not provide a representative example. In the Netherlands only for engineering and agriculture does the similarity between UE and HVE exceed the similarity of HVE with IVE. In Borghans, De Grip and Heijke (1996) it is shown that this strong interrelationship between UE level and HVE level is found for all different subcategories of engineering. Furthermore, it is remarkable that within the field of study medical laboratory, there is a high similarity between university and intermediate vocational education, while both levels have only a very low similarity with the higher vocational level. The reason for this is to be found in the occupational classification, as described in section 3. To make the classification compatible with the Irish situation people in charge of a pharmacy and those who are actually preparing and selling medicines are within the same occupational group of 'pharmacists and dispensers'. Table 10 presents the average similarities between the levels for the Netherlands.

Table 10

Average similarities between levels of education in the Netherlands

\begin{tabular}{llll}
\hline & UE & HVE & IVE \\
\hline & & & \\
& & & \\
University Education & 1.00 & 0.46 & 0.31 \\
Higher Vocational Education & 0.46 & 1.00 & 0.61 \\
Intermediate Vocational Education & 0.31 & 0.61 & 1.00 \\
\hline
\end{tabular}

Similarities between the Netherlands and Ireland

Finally, the method described in the previous section allows a comparison of the labour market position of Irish types of education with the position of Dutch types of education. To illustrate these results again the focus is on engineering. Results for other fields of study can be found in Appendix 3.

Before starting with these examples, Table 11 shows a possible problem with the analyses. The comparison between the Netherlands and Ireland is made on a joint occupational classification. The educational classifications are left, however, as they are. An advantage of not unifying educational classifications is that it is extremely difficult to compare levels between countries and furthermore that differences in educational systems might make such direct comparisons almost impossible. For that reason, we think that the method 
described in this paper provides an opportunity to avoid direct educational comparisons by linking types of education based on their labour market domain. Large differences in the level of aggregation in the data might however disturb these analyses. Table 11 provides the Dutch types of education which are closest to the Irish Master of Social Sciences. A problem with the classification is that social sciences in the Irish classification contains not only economics, law, and languages, but also sociology and psychology. In the Dutch classification these are separate groups. The results in Table 11 show however the robustness of the method in coping with these problems. Although the average similarity is lower than might be expected the similarity index picks out the right fields of study.

Table 11

Dutch types of education with the highest similarity with the Irish Master in Social Sciences

$\begin{array}{lr}\text { University Education, Economics, Econometrics \& Business Administration } & 0.68 \\ \text { University Education, Social sciences } & 0.44 \\ \text { University Education, Fine Arts } & 0.35 \\ \text { Higher Vocational Education, Interpreter \& Translator } & 0.34 \\ \text { Higher Vocational Education, Social \& Cultural } & 0.34 \\ \text { University Education, Law \& Public Administration } & 0.32\end{array}$

Table 12 compares the Dutch Higher Vocational Education Engineering, with the Irish types of education. Remarkably the university types of education in engineering show much more similarity than the technicians. This indicates that HVE in the Netherlands is closer to university education in Ireland than to the Irish vocational education. Combining this result with the fact that the similarity between HVE and university is large, leads to the conclusion that in engineering the Dutch university and HVE together play the role on the labour market, which is played by university only in Ireland. This result is however not representative for all fields of study. For only 4 educational types at higher level in the Netherlands, an Irish university level is the closest neighbour (always masters), while in 8 cases one of the three technician levels is closest, as might be expected to be the normal situation.

Table 12

Irish types of education with the highest similarity with the Dutch Higher Vocational education, Engineering 
$\begin{array}{ll}\text { Post-grad. non-degree Engineering } & 0.80\end{array}$

$\begin{array}{ll}\text { Unspecified Engineering } & 0.61\end{array}$

$\begin{array}{ll}\text { Ph.D. Engineering } & 0.53\end{array}$

$\begin{array}{ll}\text { Higher technician Engineering } & 0.39\end{array}$

Masters Multiple qualification $\quad 0.34$

Lower Technicians Engineering $\quad 0.32$

$\begin{array}{ll}\text { Higher technician Agricultural sciences } & 0.32\end{array}$

Table 13 to 18 provide the reverse analyses. For each level of engineering in Ireland the most similar types of education in the Netherlands are provided. These tables confirm the picture sketched above. The academic levels in Ireland appear to be close to both the university level and the HVE-level of engineering in the Netherlands. An exception is formed by post-graduates who not only have these similarities with university and HVE in the Netherlands, but also with Intermediate Vocational Education in Engineering. This property seems again to bridge the academic levels with the levels of the Irish Technicians. Table 16 to 18 show that for all the technician levels in engineering Intermediate vocational education in the Netherlands provides the largest similarity. Again, this result is not representative for all fields of study. All Irish fields of study at PhD or masters level do have the closest Dutch equivalent at academic level. Except for medical sciences all post graduate diploma's are closer to Dutch higher vocational education, while primary degree's again are close to the Dutch university level. Computer sciences are an exception to this. They are closer to the higher vocational level. Most fields of study at the three technician levels have, in contrast with engineering, their closest equivalent with Dutch higher vocational types of education. Besides engineering only agriculture is closer to intermediate and lower vocational education in the Netherlands. Higher technicians multiple qualifications come closer to the remainder of academics in the Netherlands.

Tables 13 to 18 indicate that although a specific match between an Irish and a Dutch type of education will have the highest similarity other types of education in the Netherlands might also overlap with an Irish type of education. Besides matching the fields of study in each country it is, therefore, also possible to investigate the average similarity between all types of eduaction at a certain level. Table 19 presents the results of this. For example the fact that the averge similarity between the Irish MA's and the Dutch HVE equals 0.12 means that the overlap between a random field of study at MA-level in Ireland has a similarity with a random field of study at the Dutch HVE-level of on average 0.12 .

Table 13

Dutch types of education with the highest similarity with the Irish Masters Engineering. 
University Education, Agriculture

Table 14

Dutch types of education with the highest similarity with the Irish Post graduates Engineering

Higher Vocational Education, Engineering

0.80

University Education, Engineering

0.79

Intermediate Vocational Education, Engineering

0.62

Higher Vocational Education, Business Administration Technology

0.61

Higher Transport \& Harbour

0.59

University Education, Economics, Econometrics \& Business Administration $\quad 0.41$

Intermediate Vocational Education, Transport \& Harbour $\quad 0.35$

University Education, Agriculture $\quad 0.35$

Lower Vocational Education, Technical $\quad 0.32$

Table 15

Dutch types of education with the highest similarity with the Irish Primary Degree Engineering.

University Education, Engineering

0.95

Higher Vocational Education, Engineering

0.88

Higher Transport \& Harbour

0.63

Higher Vocational Education, Business Administration Technology

0.62

University Education, Agriculture

0.39

University Education, Mathematics \& Natural Sciences

0.32

University Education, Economics, Econometrics \& Business Administration

0.30

Table 16

Dutch types of education with the highest similarity with the Irish Higher Technician Engineering.

Intermediate Vocational Education, Engineering

Table 17

Dutch types of education with the highest similarity with the Irish Technician Engineering. 
Table 18

Dutch types of education with the highest similarity with the Irish Lower Technician Engineering.

This table shows some interesting aspects. First, the within-level similarity in Ireland is larger than in the Netherlands. The same holds for between-level similarities. This confirms that - due to the more general character of Irish education - the overlap in the occupational domains between different fields of study is larger. Second, this table provides again a match between levels of education in Ireland and the Netherlands. The best matches have been printed bold. The three levels of university education in Ireland have their equivalent according to this measure - in the Dutch university education. In contrast to earlier findings all three levels of technicians match, however, with intermediate rather than higher vocational education in the Netherlands. This difference can be explained by the fact that in table 19 not only is a comparison made between similar fields of study in the two countries, but that the average similarity is based on a comparison of all fields of study. The overlap between an Irish and a Dutch type of education which are in the same field will be largely based on jobs which are strongly related to this field of study. In these jobs the most appropriate level for comparison is higher vocational education. The large extent of the occupational domain of Irish types of education indicates however that also many schoolleavers with technicians-degrees are in other jobs. These jobs seem to match better with the Dutch intermediate vocational level.

Table 19

Average similarity per level within and between Ireland and the Netherlands

Ph.D. M.A. P.G. P.Deg. High T. T. Low T. UE HVE IVE

$\begin{array}{lllllllllll}\text { Irish: } & & & & & & & & & & \\ \text { Ph.D. } & 0.48 & 0.34 & 0.15 & 0.24 & 0.11 & 0.09 & 0.13 & 0.16 & 0.05 & 0.05 \\ \text { M.A. } & 0.34 & 0.40 & 0.20 & 0.26 & 0.18 & 0.12 & 0.14 & \mathbf{0 . 2 2} & \mathbf{0 . 1 2} & 0.11 \\ \text { P.G. } & 0.15 & 0.20 & 0.31 & 0.21 & 0.19 & 0.19 & 0.22 & 0.16 & \mathbf{0 . 1 2} & 0.15 \\ \text { P.Deg } & 0.24 & 0.26 & 0.21 & 0.24 & 0.12 & 0.09 & 0.10 & 0.17 & 0.09 & 0.08 \\ \text { High T. } & 0.11 & 0.18 & 0.19 & 0.12 & 0.36 & 0.34 & 0.38 & 0.10 & \mathbf{0 . 1 2} & 0.20 \\ \text { T. } & 0.09 & 0.12 & 0.19 & 0.09 & 0.34 & 0.50 & 0.63 & 0.05 & 0.08 & 0.23\end{array}$




$\begin{array}{lllllllllll}\text { Low T. } & 0.13 & 0.14 & 0.22 & 0.10 & 0.38 & 0.63 & 0.96 & 0.06 & 0.09 & \mathbf{0 . 3 0} \\ & & & & & & & & & & \\ \text { Dutch: } & & & & & & & & & \\ \text { UE } & \mathbf{0 . 1 6} & \mathbf{0 . 2 2} & \mathbf{0 . 1 6} & \mathbf{0 . 1 7} & 0.10 & 0.05 & 0.06 & 0.21 & 0.10 & 0.08 \\ \text { HVE } & 0.05 & 0.12 & 0.12 & 0.09 & 0.12 & 0.08 & 0.09 & 0.10 & 0.24 & 0.15 \\ \text { IVE } & 0.05 & 0.11 & 0.15 & 0.08 & \mathbf{0 . 2 0} & \mathbf{0 . 2 3} & \mathbf{0 . 3 0} & 0.08 & 0.15 & 0.36\end{array}$

\section{Conclusions}

In this paper a comparison has been made of the Irish and the Dutch occupational structure of types of education. This comparison has been based upon a common occupational classification, which is an aggregation of the national occupational classification in the two countries. The occupational structure has been measured by two indexes: the index of the occupational domain and the similarity index. The index of the occupational domain shows the extent of the occupational domain of each type of education. The similarity index provides information about the overlap in the occupational domain of two types of education. Due to data limitations the focus in the paper is on higher education. There are considerable differences between Ireland and the Netherlands with respect to the educational level of the labour force. In Ireland $11 \%$ of the labour force has a higher educational qualification, while for the Netherlands this fraction is $19 \%$. Furthermore, as shown in section 3, there are also important differences in the relative size of the occupations distinguished, and in the participation of higher educated within each occupation.

The two indexes can be used within one country to indicate to students who have to make their educational choice what are the switching opportunities with a particular type of education, and which competing types of education have largely overlapping occupational domains. By using the indexes in an international comparative context two other aims can be realized. First, the indexes provide information about the way the labour market in each country is structured with regard to the educational qualifications of people. It is shown that the more generally oriented Irish system leads to larger occupational domains and to larger overlaps in occupational domains between fields of study. Within the more stratified Dutch educational system, students have to make early decisions about the level and field of study. This stratification seems to lead to more overlap between different levels of education within the same field, which might indicate that the Dutch system performs worse in selecting people for the right level. Furtermore the analyses show the special role of post graduate programs in Ireland, which bring students with a primary degree closer to the more vocationally oriented labour market of the technicians.

A second possibility the indexes offer for international comparison is that the similarity between Irish and Dutch types of education can be measured. This makes it possible to detect which qualifications in both countries have the best match with regard to the 
occupations they lead to. This way of comparing educational systems might offer useful information for projects concerning the international comparability of types of education. It is shown that most courses at university level in the Netherlands have their equivalent in Ireland in the same field of study at Master level. Vica versa, most Irish university qualifications at all levels can be matched with a Dutch university qualification. For the technicians this picture is different, however. It appears that higher technicians in engineering and agricultural sciences can be better matched with intermediate rather than higher level in the Netherlands. When furthermore not only the type of education within the same field is considered, but a comparison is made with all types of education at a certain level, the three levels of technicians in Ireland seem also on average to be closer to the intermediate rather than to higher level of vocational education in the Netherlands.

The paper shows that the similarity indexes presented in this paper provide a useful tool to compare educational systems between countries. There are, however, also some difficulties to be dealt with. First, a common occupational classification depends on the comparability of the national classifications. Further effort for harmonization would, therefore, from this point of view be very important. Even if occupational classifications are harmonized, however, some specific problems will remain, due to the differences in the organization of work in different countries. Finally, the results of these analyses could be improved if data could be used for lower levels of aggregation of the types of education, since clusters of different courses might bias the results.

\section{References}

Borghans, L. (1992), 'A Histo-Topographic Map of the Dutch University Studies'. ROA-W-92/5E, Maastricht.

Borghans, L., A. de Grip and H. Heijke (1996), 'Concepts and Methodology for Labour Market Forecasts by Occupation and Qualification in the Context of a Flexible Labour Market'. CEDEFOP Document, Contribution to the Ciretoq network, Thessaloniki.

Breen, R., and C. Whelan (1995), 'Investment in Education: Educational Qualifications and Class of Entry in the Republic of Ireland', Mimeo ESRI, Ireland.

De Graaf, P., and W. Ultee (1995), 'Transition from Education to First Occupation in the

Mimeo, Nijmegen University, Nijmegen

International Labour Organisation (1969), International Standard Classification of Occupations: Revised Edition 1968. Geneva: International Labour Office.

Müller, W., Y. Shavit and P. Ucen (1996), The Institutional Imbeddedness of the Stratification $P$

a Comperative Study of Qualifications and Occupations in 13 Countries, Paper for the Provence Workshop of the ESF Network on Transition in Youth. La Ciotat, September 18-21, 
1996.

Organisation for Economic Co-operation and Development (1971). Occupational and Educational Structures of the Labour Force and Levels of Economic Development: Further Analyses and Statistical Data. Paris: Organisation for Economic Co-operation and Development.

Warnken, G. (1986). 'Zur Entwicklung der "Internen" Anpassungsfühigkeit den Berufe bis zum Jahre 2000. Projektionen unter den Annahmen den Wachstumzenarien der Prognos-Studie'. Mitteilungen aus der Arbeidsmarkt- und Berufsforschung 1, pp. 119-133. 


\section{Appendix 1 Common occupational classification}

Name of the common occupational group

Names of the Irish occupational groups within this common group

Names of the Dutch occupational groups within this common group

1 farmers

201 farmers (horse, pig or poultry)

202 other farmers

203 farmers' sons and daughters assisting on farm

204 farmers' other relatives assisting on farm

611 farmers agriculture

612 farmers horticulture

2 farm managers

205 farm managers

601 farm managers agriculture

602 farm managers horticulture

609 farm managers n.e.c.

680 managers agrarian concerns

3 agricultural labourers

206 agricultural labourers

217 bog labourers

218 other turf workers

621 general farm workers

622 field crop and vegetable farm workers

624 farm machinery workers

4 gardeners-skilled

208 gardeners-skilled

207 market gardeners and nurserymen (landholders)

613 gardeners

5 gardeners (unskilled)

209 groundsmen, gardeners (unskilled) and gardeners' labourers

623 undergardeners

6 other agricultural workers

211 other agricultural workers

629 agricultural workers n.e.c.

7 foresters and skilled forestry workers

212 foresters and skilled forestry workers

631 foresters

8 forestry labourers and workers

213 forestry labourers and workers

632 foresty workers 
9 fishermen

214 fishery board agents and inspectors

215 fishermen, etc.

641 fishermen

649 oyster culturists

10 miners

216 mine and quarry workers

711 miners

712 mineral treaters

11 telephone installers

219 telephone installers, repairers and mechanics

856 telephone and telegraph installers

12 linesmen

221 linesmen and cable jointers

857 linemen

13 electricians and electrical fitters

222 electricians and electrical fitters

223 electrical and electronics engineering technicians not included elsewhere

225 other electrical fitters and related workers

851 electrical fitters

852 electronics fitters

853 electrical equipment assemblers

855 electrical wiremen

14 radio and television mechanics

224 radio and television mechnics

854 radio and television repairmen

15 motor mechnics

226 motor mechnics

843 motor vehicle mechanics

16 vehicle assemblers

227 bicycle repairers and mechanics

229 assemblers of vehicles, motor cycles and bicycles

230 other vehicle builders and skilled workers in motor vehicle and cycle assembly

846 vehicle assemblers

17 fitters and other mechanics

228 fitters and other mechanics

841 machinery fitters

844 aircraft engine mechanics

845 machinery repairers

18 plumbers and gas fitters

231 plumbers and gas fitters

871 plumbers 
879 fitters

19 sheet metal workers

232 sheet metal workers

873 sheet-metal workers

20 structural metal and metal plate workers

233 structural metal and metal plate workers

874 structural metal preparers

21 welders and cutters

234 welders and cutters

872 welders

22 machine tool setters and operators

235 machine tool setters and operators

833 machine-tool setter-operators

834 machine-tool operators

835 metal polishers

836 machine-tool operators n.e.c.

23 precision instrument and watch and clock makers

236 precision instrument and watch and clock makers

842 clock makers

24 goldsmiths, silversmiths and jewellery makers

237 goldsmiths, silversmiths and jewellery makers

880 jewellery workers

25 metal coaters, platers, benders, etc.

239 metal coaters, platers, benders, etc.

728 metal platers

26 technical inspectors

240 metal goods inspectors, assemblers and testers

406 technical inspectors not included elsewhere

849 controllers machinery

859 controllers electrotechnical products

944 controllers products

27 smiths and toolmakers

241 metal furniture workers, jointers and solderers

244 blacksmiths and other metal workers

831 smiths

832 toolmakers

839 blacksmiths and toolmakers n.e.c.

28 wood preparation workers

245 wood preparation workers

731 wood treaters

732 sawyers 
29 cabinet makers

246 cabinet makers

811 cabinetmakers

819 cabinetmakers and related workers n.e.c.

30 carpenters and joiners

247 carpenters and joiners

954 carpenters

31 woodworking machinists

248 woodworking machinists

812 woodworking-machine operators

32 woodware makers

249 wood carvers, finishers and assemblers

250 other wood and wooden furniture makers

888 woodware makers

33 tanners, fellmongers and pelt dressers

251 tanners, fellmongers and pelt dressers

760 tanners

792 fur tailors

34 boot and shoe makers

252 boot and shoe makers (factory): semi-skilled

253 boot and shoe makers (factory): skilled

254 boot and shoe makers and repairers (not factory)

801 shoemakers

802 shoe cutters, lasters and related workers

35 other leather workers

255 other leather workers

803 leather goods makers

36 spinners, doublers, winders and reelers

256 spinners, doublers, winders and reelers

751 fibre preparers

752 spinners

37 weavers and related workers

257 weavers and related workers

753 weaving-machine setters

754 weavers

38 bleachers, dyers and finishers

258 bleachers, dyers and finishers

756 bleachers

39 knitters

259 knitters and knitting/hosiery machine operatives

755 knitters 
40 occupations related to spinning, weaving, knitting and dyeing 260 occupations related to spinning, weaving, knitting and dyeing 759 spinners, weavers, knitters and related workers n.e.c.

41 upholsterers

261 upholsterers and related workers

796 upholsterers

42 tailors and dressmakers

262 tailors and dressmakers

263 cutters

791 tailors

794 patternmakers

799 tailors, dressmakers and related workers n.e.c.

43 sewers

264 sewers, embroiderers and machinists

265 other clothing workers

795 sewers

44 mill workers

266 mill workers: semi-skilled

267 mill workers: skilled

771 grainmillers

45 bakers

268 bakers, pastrycooks and biscuit makers

776 bakers

46 sugar processors

269 makers of sugar and chocolate confectionery, jams and jellies 772 sugar processors

47 milk processors and makers of dairy products 270 milk processors and makers of dairy products 775 dairy product processors

48 butchers

271 meat curers, canners and preservers

773 butchers

774 food preservers

49 food and beverage processors n.e.c.

272 other makers of food

779 food and beverage processors n.e.c.

50 brewers

273 makers of beverages

777 brewers

51 makers of tobacco products 
274 makers of tobacco products

781 tobacco preparers

782 cigar makers

783 cigarette makers

52 makers of paper and paperboard

275 makers of paper and paperboard

733 paper pulp preparers

734 paper makers

741 crushers

53 makers of products of paper and paperboard

276 makers of products of paper and paperboard

910 paper products makers

54 compositors

277 compositors, monotype and linotype operators

921 compositors

55 printers

278 printers (so described)

279 printing machine minders and feeders

280 printing press operators

281 other paper and printing workers

922 printing pressmen

923 stereotypers

924 printing engravers

925 photo-engravers

926 bookbinders

927 photographic darkroomworkers

929 silk-screen printers

56 metal casters, moulders, setters, drawers, etc., furnace and smelter workers (metal 238 metal casters, moulders, setters, drawers, etc., furnace and smelter workers (metal 713 well drillers

721 metal smelting furnacemen

722 metal rolling-mill workers

723 metal melters

724 metal casters

725 metal moulders

726 metal annealers

727 metal drawers

729 metal processors n.e.c.

57 paramedical personnel

242 dental, orthopaedic and optical craft workers

386 Health inspectors, cardiographers, nutritionists, etc.

390 Opticians, therapists, chiropodists, medical X-ray personnel, etc.

69 dietitians

75 optometrists

76 physiotherapists 
77 medical x-ray technicians

79 medical related workers n.e.c.

58 gas and chemical workers

282 gas and chemical workers

742 cookers

743 filter operators

744 still and reactor operators

745 petroleum-refining workers

749 chemical processors n.e.c.

59 workers in rubber and rubber products

284 workers in rubber and rubber products

285 workers in plastics

901 rubber makers

902 tire makers

60 glassformers

286 glassformers, potters and related workers not included elsewhere

283 glass and ceramics workers

891 glass formers

892 potters

893 glass and ceramics kilnmen

894 glass engravers

899 glass formers, potters and related workers n.e.c.

61 non-metallic mineral product makers

287 non-metallic mineral product makers

295 other tradesmen

952 reinforced concreters

953 roofers

956 insulators

957 glaziers

959 construction workers n.e.c.

62 craftsmen not included elsewhere

288 craftsmen not included elsewhere

941 musical instrument makers

942 basketry weavers

63 other production workers

289 other production workers

949 other production workers

64 clerical supervisors

290 clerks of works

328 clerical supervisors

300 clerical supervisors

65 builders and contractors

291 builders and contractors 
958 contractors

66 bricklayers

292 bricklayers

943 concrete makers

951 bricklayers

67 masons and stone cutters

293 masons and stone cutters

820 stonecutters

68 plasterers

294 plasterers

955 plasterers

69 commercial designers

296 interior decorating consultants and designers

403 Industrial designers

162 commercial designers

70 painters and decorators

297 painters and decorators

931 painters

939 painters n.e.c.

71 crane and hoist operators; riggers and cable splicers

298 crane and hoist operators; riggers and cable splicers

972 riggers

973 crane and hoist operators

72 earth-moving machinery operators

299 earth moving and other construction machinery operators

974 earth-moving machinery operators

991 road-building workers

73 stationary engine operators

302 stationary engine operators

961 power-generating machinery operators

969 stationary engine operators n.e.c.

74 foremen and supervisors of manual workers 307 foremen and supervisors of manual workers 700 production supervisors and general foremen 701 supervision personnel ind. prod. departments 702 supervision personnel building-ind.

75 dock labourers

300 dock labourers

999 dockers

76 lorry drivers' helpers 
303 lorry drivers' helpers

979 fork-lift truck drivers

77 loaders

304 porters working in the transport sector

301 packers and bottlers

305 other porters

971 loaders

78 railway engine drivers and firemen

308 railway engine drivers and firemen

983 railway engine drivers

79 signalmen and level crossing keepers

309 signalmen and level crossing keepers

984 railway brakemen

80 sailors: skilled

310 sailors: skilled

982 ships' engine-room ratings

81 other sailors

311 other sailors

981 ships' deck ratings

82 drivers

312 drivers of buses

313 drivers of other road passengers vehicles

314 drivers of road goods vehicles

315 other transport equipment operators

985 motor vehicle drivers

989 transport equipment operators

83 transport controllers

319 air and land transport controllers

320 other transport and communication inspectors and supervisors

321 ticket chekckers, collectors and inspectors (railways)

322 bus conductors

351 railway station masters

359 transport supervisors n.e.c.

360 transport conductors

84 postmen

323 postmen and post office sorters

324 messengers

352 postmasters

370 mail distribution clerks

85 telephone operators

325 telephone, telegraph and radio operators

380 telephone operators 
86 ships' officers

377 ships' officers

42 ships' deck officers and pilots

87 aircraft pilots

378 aircraft pilots, navigators and flight engineers

41 aircraft pilots

88 stock clerks

326 warehouse and despatch clerks

391 stock clerks

89 typists

316 typists and key-punch operators

321 typists

322 card-punching machine operators

90 book-keeping, cashiers and related workers

317 book-keeping, cashiers and related workers

331 bookkeepers

339 bookkeepers n.e.c.

341 bookkeeping machine operators

91 computing machine operators

318 computing machine operators

342 automatic data-processing machine-operators

92 clerial workers n.e.c.

327 clerial workers not included elsewhere

392 material planning clerks

393 correspondence clerks

394 receptionists

395 library clerks

399 clerks n.e.c.

593 medical assistants

998 civil servants, specialisation unknown

93 government executive officials

367 government executive officials

410 Technical and related workers not included elsewhere

310 government executive officials

94 shopkeepers and managers of shops

329 managers of filling stations and garages

331 other managers in wholesale or retail trade

332 proprietors of filling stations or garages

334 other proprietors in wholesale or retail trade

401 directors wholesale

402 managers wholesale

411 directors retail trade

412 managers retail trade 
420 sales supervisors and buyers

431 shopkeepers foodstuff

432 shopkeepers drugstore

433 shopkeepers clothes

434 shopkeepers shoes

435 shopkeepers furniture

436 shopkeepers ironware

437 shopkeepers prints

438 shopkeepers photography

439 shopkeepers n.e.c.

95 cafe owners

330 bar or public house managers

333 publicans, wine merchants, off-licence proprietors, etc.

513 cafe owners

96 commercial travellers and manufacturers' agents

335 commercial travellers and manufacturers' agents

451 salesmen

452 purchasing agents

461 technical representatives

462 other commercial representatives

97 shop assistants

336 shop assistants and related workers

481 shop-assistants

490 sales workers

98 waiters

337 bar attendants

348 waiters and waitresses

349 canteen and related workers

532 waiters

99 insurance agents

338 insurance agents

339 insurance brokers and financial agents - higher professional

340 other insurance brokers and financial agents

471 insurance agents

100 street vendors

342 roundsmen

343 street vendors, hawkers, newspaper sellers

472 canvassers

482 streettraders

101 auctioneers

344 auctioneers, valuers and other salesmen

341 Valuation surveyors

473 auctioneers 
102 livestock (non-farm) workers

210 livestock (non-farm) workers

986 animal drivers

103 managers of hotels, restairants, hostels, clubs, etc.

345 managers of hotels, restairants, hostels, clubs, etc.

501 managers hotel and catering industry

502 managers hotel and catering industry

518 managers lodging service

104 working proprietors in catering/lodging services not included elsewhere

346 working proprietors in catering/lodging services not included elsewhere

511 hotel owners

512 restaurant owners

514 canteen owners

519 catering establishment owners

105 caretakers

347 matrons, superintendents, supervisors of schools etc.

353 caretakers

520 housekeeping supervisors

551 building caretakers

106 chefs and cooks

350 chefs and cooks

531 cooks

107 housekeeping service workers

351 domestic servants and related workers

359 air hostesses or stewards

541 housekeeping service workers

108 cleaners

352 cleaners

552 charworkers, cleaners and related workers

109 laundry and dry cleaning workers

354 laundry and dry cleaning workers

560 launders

110 barbers

355 barbers, hairdressers and beauty consultants

570 barbers

111 policemen

357 garda sergeants and lower ranks

356 garda siochana (senior ranks)

582 policemen

112 watchmen and related workers

358 watchmen and related workers 
581 fire-fighters

589 protective service workers

113 dental nurses

360 dental nurses

64 dental assistants

114 attendants

361 hospital and ward orderlies: hospital porters and attendants

542 attendants

115 broadcasting station operators

362 broadcasting operators; film editors; projectionists

860 broadcasting station operators

116 proprietors in other service industries

363 proprietors in other service industries

368 Managers and company secretaries

211 managers concerns

212 independent managers

213 general managers

214 production managers

219 managers n.e.c.

117 other service workers

364 other service workers

591 guides

592 undertakers and embalmers

599 other service workers

118 fotographers

401 photographers and camera operators

163 fotographers

119 labourers and unskilled workers not included elsewhere 306 labourers and unskilled workers not included elsewhere 992 sanitation workers

120 legislative officials and government administrators

365 Legislative officials and government administrators

366 Senior officials in Civil Service and Local Authorities

201 legislative officials

202 government administrators

121 Personnel officers

408 Personnel officers

194 personnel specialists

122 Physical scientists

369 Physical scientists

11 chemists 
12 phycisists

13 physical scientist not elsewhere classified

123 Physical science technicians

370 Physical science technicians

14 physical science techn.

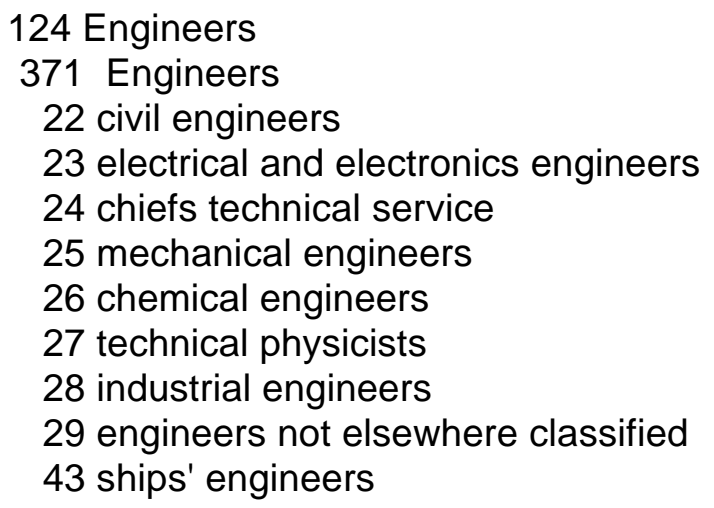

125 Architects and town planners

372 Architects and town planners

21 architects and town planners

126 Technologists

373 Technologists

220 telecommunications technicians

375 Estimators, work study officers, quality control technicians, etc.

33 civil engineering technicians

34 electrical and electronics engineering technicians

35 mechanical engineering technicians

36 chemical eng. techn.

37 metallurgists

39 engineering techn. n.e.c.

127 Chartered, hydrographic and quantity surveyors

374 Chartered, hydrographic and quantity surveyors

31 geodetic engineers

128 Draughtsmen
376 Draughtsmen
32 draughtsmen

129 Professional workers not included elsewhere

379 Veterinary pathologists

409 Professional workers not included elsewhere

191 librarians

192 sociologists

195 philologists

199 other professional, technical and related workers

130 bacteriologists 
380 Bacteriologists, pathologists, pharmacologists, physiologists

52 bacteriologists

131 Other life scientists

381 Other life scientists

51 biologists

132 Life sciences technicians

382 Life sciences technicians

53 agronomists

54 life sciences technicians

133 Medical practitioners and midwives

383 Medical practitioners

61 medical doctors

73 prof. midwives

134 Dental practitioners

384 Dental practitioners

63 dentists

135 Pharmacists and dispensers

385 Pharmacists and dispensers

67 pharmacists

68 pharmaceutical assistants

136 Veterinary surgeons

387 Veterinary surgeons

388 Cattle testers and milk inspectors

65 veterinarians

137 Nurses

389 Nurses

71 prof. nurses

72 nursing pers. n.e.c.

74 midwivery pers. n.e.c.

138 Business, economic and marketing consultants, advisers and researchers

391 Business, economic and marketing consultants, advisers and researchers

90 economists

139 Mathematicians, statisticians and actuaries

392 Mathematicians, statisticians and actuaries

81 statiticians

82 mathematicians

84 statistical and mathematical technicians

85 statistical assistants

140 Systems analysts and computer programmers

393 Systems analysts and computer programmers

83 systemanalysts 
141 Accountants

394 Accountants

110 accountants

142 Judges, barristers and solicitors

395 Judges, barristers and solicitors

121 lawyers

122 judges

129 jurists n.e.c.

143 Professed clergymen and nuns

396 Professed clergymen and nuns

141 ministers of religion

144 Other religious occupations

397 Other religious occupations

149 workers in religion n.e.c.

145 Teachers

398 University professors and lecturers

399 Teachers

131 secundary and higer education teachers

133 primary edcuation teachers

134 special education teachers

135 pre-primary education teachers

139 school principals

146 Authors, journalists and editors

400 Authors, journalists and editors

151 authors

159 journalists

179 newsreaders

147 Painters, sculptors and commercial artists

402 Painters, sculptors and commercial artists

161 sculptors

148 Actors, entertainers and musicians

404 Actors, entertainers and musicians

171 musicians

172 dancers

173 actors

174 producers performing arts

175 circus performers

149 sportsmen

405 Sportsmen and related workers

180 sportsmen

150 Social workers

407 Social workers 
193 social workers

151 officers and soldiers

411 Commissioned officers

412 Other ranks

660 soldiers

152 Residual

500 Residual

243 refuleers, oilers and greasers

413 Gainfully occupied but occupation not stated

650 profession unknown

670 conscripts

153 Not working

501 Not working

422 Persons looking for first regular job

993 sheltered workshop workers 


\section{Appendix 2 Some tables of similarities between levels}

Table 2.1

Similarities between levels of education in natural sciences in Ireland

\begin{tabular}{|c|c|c|c|c|c|c|c|}
\hline & Ph.D. & M.A. & P.G. & P.Deg & High T. & $\mathrm{T}$. & Low $\mathrm{T}$. \\
\hline Ph.D. & 1.00 & 0.96 & 0.59 & 0.96 & 0.18 & 0.06 & 0.31 \\
\hline Masters & 0.96 & 1.00 & 0.69 & 0.90 & 0.28 & 0.15 & 0.38 \\
\hline Post-grad. non-degree & 0.59 & 0.69 & 1.00 & 0.55 & 0.75 & 0.69 & 0.77 \\
\hline Primary degree & 0.96 & 0.90 & 0.55 & 1.00 & 0.24 & 0.13 & 0.38 \\
\hline Higher technician & 0.18 & 0.28 & 0.75 & 0.24 & 1.00 & 0.99 & 0.89 \\
\hline Technician & 0.06 & 0.15 & 0.69 & 0.13 & 0.99 & 1.00 & 0.88 \\
\hline Lower Technician & 0.31 & 0.38 & 0.77 & 0.38 & 0.89 & 0.88 & 1.00 \\
\hline
\end{tabular}

Table 2.2

Similarities between levels of education in social sciences in Ireland

Ph.D. M.A. P.G. P.Deg High T. T. Low T.

\begin{tabular}{llllllll} 
Ph.D. & 1.00 & 0.86 & 0.37 & 0.91 & 0.36 & - & - \\
Masters & 0.86 & 1.00 & 0.53 & 0.86 & 0.55 & - & - \\
Post-grad. non-degree & 0.37 & 0.53 & 1.00 & 0.62 & 0.93 & - & - \\
Primary degree & 0.91 & 0.86 & 0.62 & 1.00 & 0.57 & - & - \\
Higher technician & 0.36 & 0.55 & 0.93 & 0.57 & 1.00 & - & - \\
Technician & - & - & - & - & - & - & - \\
Lower Technician & - & - & - & - & - & - & - \\
\hline
\end{tabular}

Table 2.3

Similarities between levels of education in agricultural sciences in Ireland

Ph.D. M.A. P.G. P.Deg High T. T. Low T.

$\begin{array}{llllllll}\text { Ph.D. } & 1.00 & 0.74 & - & 0.66 & 0.31 & 0.13 & - \\ \text { Masters } & 0.74 & 1.00 & - & 0.64 & 0.42 & 0.19 & - \\ \text { Post-grad. non-degree } & - & - & - & - & - & - & - \\ \text { Primary degree } & 0.66 & 0.64 & - & 1.00 & 0.35 & 0.17 & - \\ \text { Higher technician } & 0.31 & 0.42 & - & 0.35 & 1.00 & 0.61 & - \\ \text { Technician } & 0.13 & 0.19 & - & 0.17 & 0.61 & 1.00 & - \\ \text { Lower Technician } & - & - & - & - & - & - & -\end{array}$

Table 2.4

Similarities between levels of education in medical sciences in Ireland 
Ph.D. M.A. P.G. P.Deg High T. T. Low T.

\begin{tabular}{llllllll}
\hline & & & & & & & \\
Ph.D. & 1.00 & 0.98 & 0.98 & 0.96 & 0.02 & 0.02 & 0.01 \\
Masters & 0.98 & 1.00 & 0.95 & 0.99 & 0.03 & 0.02 & 0.03 \\
Post-grad. non-degree & 0.98 & 0.95 & 1.00 & 0.96 & 0.03 & 0.01 & 0.02 \\
Primary degree & 0.96 & 0.99 & 0.96 & 1.00 & 0.04 & 0.01 & 0.04 \\
Higher technician & 0.02 & 0.03 & 0.03 & 0.04 & 1.00 & 0.35 & 0.97 \\
Technician & 0.02 & 0.02 & 0.01 & 0.01 & 0.35 & 1.00 & 0.16 \\
Lower Technician & 0.01 & 0.03 & 0.02 & 0.04 & 0.96 & 0.16 & 1.00 \\
\hline
\end{tabular}

Table 2.5

Similarities between levels of education in computer science in Ireland

Ph.D. M.A. P.G. P.Deg High T. T. Low T.

Ph.D.

Masters

Post-grad. non-degree

Primary degree

Higher technician

Technician

Lower Technician

$\begin{array}{llllll}- & - & - & - & - & - \\ 1.00 & 0.81 & 0.81 & 0.70 & 0.63 & 0.34 \\ 0.81 & 1.00 & 0.99 & 0.97 & 0.95 & 0.57 \\ 0.81 & 0.99 & 1.00 & 0.98 & 0.94 & 0.56 \\ 0.70 & 0.97 & 0.98 & 1.00 & 0.97 & 0.64 \\ 0.63 & 0.95 & 0.94 & 0.97 & 1.00 & 0.67 \\ 0.34 & 0.57 & 0.56 & 0.64 & 0.67 & 1.00\end{array}$

Table 2.6

Similarities between levels of education in agriculture in the Netherlands

\begin{tabular}{llll}
\hline & UE & HVE & IVE \\
\hline University Education & & & \\
Higher Vocational Education & 1.00 & 0.82 & 0.10 \\
Intermediate Vocational Education & 0.82 & 1.00 & 0.48 \\
& 0.10 & 0.48 & 1.00 \\
\hline
\end{tabular}


Table 2.7

Similarities between levels of education in nursing and paramedical service in the Netherlands

\begin{tabular}{llll}
\hline & UE & HVE & IVE \\
\hline University Education & 1.00 & 0.06 & 0.01 \\
Higher Vocational Education & 0.06 & 1.00 & 0.71 \\
Intermediate Vocational Education & 0.01 & 0.71 & 1.00 \\
\hline
\end{tabular}

Table 2.8

Similarities between levels of education in medical laboratory in the Netherlands

\begin{tabular}{llll}
\hline & UE & HVE & IVE \\
\hline University Education & & & \\
Higher Vocational Education & 1.00 & 0.01 & 0.85 \\
Intermediate Vocational Education & 0.01 & 1.00 & 0.26 \\
& 0.85 & 0.26 & 1.00 \\
\hline
\end{tabular}

Table 2.9

Similarities between levels of education in economics and business administration in the Netherlands

\begin{tabular}{llll}
\hline & UE & HVE & IVE \\
\hline University Education & & & \\
Higher Vocational Education & 1.00 & 0.46 & 0.31 \\
Intermediate Vocational Education & 0.46 & 1.00 & 0.77 \\
& 0.31 & 0.77 & 1.00 \\
\hline
\end{tabular}

Table 2.10

Similarities between levels of education in administrative, legal and fiscal education in the Netherlands

\begin{tabular}{llll}
\hline & UE & HVE & IVE \\
\hline University Education & & & \\
Higher Vocational Education & 1.00 & 0.44 & 0.18 \\
Intermediate Vocational Education & 0.44 & 1.00 & 0.80 \\
& 0.18 & 0.80 & 1.00 \\
\hline
\end{tabular}

Table 2.11

Similarities between levels of education in social and cultural in the Netherlands 


\begin{tabular}{llll}
\hline & UE & HVE & IVE \\
\hline & & & \\
University Education & 1.00 & 0.54 & 0.42 \\
Higher Vocational Education & 0.54 & 1.00 & 0.74 \\
Intermediate Vocational Education & 0.42 & 0.74 & 1.00 \\
& & & \\
\hline
\end{tabular}




\section{Appendix 3 Similarities between Dutch and Irish types of education}

HVE, Teacher training

HVE, Interpreter\& Translator Masters Social sciences

HVE, Vocational Education, Agriculture Technician Agricultural sciences

Unspecified Agricultural sciences

0.41

Higher technician Agricultural sciences

0.34

HVE, Non-medical laboratory Technician Medical sciences

Higher technician Natural sciences

0.93

Technician Natural sciences

HVE, Engineering

Masters Engineering

Primary degree Engineering

0.88

Post-grad. non-degree Engineering

0.80

Higher Transport \& Harbour

Masters Engineering

Primary degree Engineering

0.63

Post-grad. non-degree Engineering

0.59

HVE, Medical Laboratory

Higher technician Medical sciences

0.61

HVE, Nursing \& Physiotherapy etc.

Higher technician Medical sciences

0.74

Lower technician Medical sciences

0.74

HVE, Commerce \& Administration

Higher technician Social sciences $\quad 0.44$

Unspecified Computer science $\quad 0.44$

Higher technician Multiple qualifications $\quad 0.40$

Technician Computer science $\quad 0.39$

Higher technician Computer science 0.36

Masters Multiple qualifications $\quad 0.35$

Higher technician Agricultural sciences $\quad 0.35$

HVE, Business Administration Technology

Masters Engineering

0.65

Primary degree Engineering $\quad 0.62$

Post-grad. non-degree Engineering 0.61

Unspecified Computer science 0.59

Higher technician Compuer science $\quad 0.56$

HVE, Administrative, Legal \& Fiscal

Lower Technician Multiple qualifications $\quad 0.64$

HVE, Social \& Cultural

Post-grad. non-degree Social sciences $\quad 0.80$ 
HVE, Hotel \& Catering Industry

Higher technician Agricultural sciences $\quad 0.33$

Higher technician Multiple qualifications $\quad 0.32$

Masters Multiple qualifications $\quad 0.32$

UE, Agriculture

Masters Engineering $\quad 0.40$

Primary degree Engineering $\quad 0.39$

Ph.D. Agricultural sciences $\quad 0.37$

Post-grad. non-degree Engineering 0.35

UE, Mathematics \& Natural Sciences

Masters Natural sciences $\quad 0.94$

Ph.D. Natural sciences $\quad 0.90$

UE, Engineering

Masters Engineering 0.98

Primary degree Engineering $\quad 0.95$

UE, Veterinary \& Medical Sciences \& Dentistry

Post-grad. non-degree Medical sciences 0.98

Primary degree Medical sciences $\quad 0.97$

Ph.D. Medical sciences $\quad 0.97$

Masters Medical sciences $\quad 0.96$

UE, Pharmacy

Unspecified Medical sciences $\quad 0.65$

UE, Economics, Econometrics \& Business Administration
Masters Social sciences

Unspecified Social sciences $\quad 0.60$

UE, Law \& Public Administration

UE, Social Sciences

Masters Social sciences $\quad 0.44$

UE, Fine Arts

Masters Social sciences $\quad 0.35$

Ph.D., Engineering

UE, Mathematics \& Natural Sciences $\quad 0.78$

UE, Engineering $\quad 0.68$

Ph.D., Natural sciences

UE, Mathematics \& Natural Sciences $\quad 0.90$

Ph.D., Social sciences

UE, Economics, Econometrics, Business Administration $\quad 0.46$

Ph.D., Agricultural sciences

UE, Agriculture $\quad 0.37$

Ph.D., Medical sciences

UE, Veterinary \& Medical Sciences \& Dentistry 0.97

Masters Engineering

52 
Masters Natural sciences

UE, Mathematics \& Natural Sciences

Masters Social sciences

UE, Economics, Econometrics \& Business Administration $\quad 0.68$

Masters Agricultural sciences

UE, Mathematics \& Natural Sciences $\quad 0.36$

Masters Medical sciences

UE, Veterinary \& Medical Sciences \& Dentistry 0.96

Masters Computer science

UE, Mathematics, Natural Sciences

0.63

Post-grad. non-degree Engineering

HVE, Engineering $\quad 0.80$

UE, Engineering $\quad 0.79$

Post-grad. non-degree Natural sciences

HVE, non-medical laboratory $\quad 0.67$

IVE, Non-medical laboratory $\quad 0.64$

UE, Mathematics \& Natural Sciences $\quad 0.60$

Post-grad. non-degree Social sciences

HVE, Social \& Cultural $\quad 0.80$

Post-grad. non-degree Medical sciences

UE, Veterinary \& Medical Sciences \& Dentistry 0.98

Post-grad. non-degree Computer science

HVE, Business Administration Technology 0.53

Primary degree Engineering

UE, Engineering $\quad 0.95$

HVE, Engineering $\quad 0.88$

Primary degree Natural sciences

UE, Mathematics \& Natural Sciences 0.82

Primary degree Social sciences

UE, Economics, Econometrics \& Business Administration $\quad 0.51$

Primary degree Medical sciences

UE, Veterinary \& Medical Sciences \& Dentistry 0.97

Primary degree Computer science

HVE, Business Administration Technology 0.52

Higher technician Engineering

IVE, Engineering

Higher technician Natural sciences

HVE, non-medical laboratory

0.93

IVE, non-medical laboratory

0.90 
Higher technician Social sciences

HVE, Social \& Cultural $\quad 0.70$

IVE, Social \& Cultural $\quad 0.65$

Higher technician Agricultural sciences

IVE, Agriculture 0.52

Lower Vocational Education, Agriculture $\quad 0.50$

Higher technician Medical sciences

HVE, Nursing \& Physiotherapy 0.74

Higher technician Computer science

HVE, Business Administration Technology 0.56

Higher technician Multiple qualifications

UE, n.e.c.

0.68

IVE, n.e.c.

0.65

Technician Engineering

IVE, Engineering

0.76

Technician Natural sciences

HVE, non-medical laboratory $\quad 0.93$

IVE, non-medical laboratory $\quad 0.92$

Technician Agricultural sciences

Lower Vocational Education, Agriculture $\quad 0.94$

IVE, Agriculture $\quad 0.94$

Technician Medical sciences

HVE, non-medical laboratory $\quad 0.95$

IVE, non-medical laboratory $\quad 0.90$

Technician Computer science

HVE, Business Administration Technology 0.54

Technician Multiple qualifications

HVE, non-medical laboratory $\quad 0.47$

IVE, non-medical laboratory $\quad 0.46$

IVE, Engineering $\quad 0.41$

Lower Technician Engineering

IVE, Engineering $\quad 0.77$

Lower Technician Natural sciences
HVE, non-medical laboratory

IVE, non-medical laboratory $\quad 0.78$

Lower Technician Medical sciences

HVE, Nursing \& Physiotherapy etc. $\quad 0.74$

Lower Technician Computer science

HVE, Business Administration Technology 0.41

Lower General Secondary Education $\quad 0.40$

Higher General Secondary Education $\quad 0.40$

IVE, Administrative, legal \& fiscal $\quad 0.39$

Lower Vocational Education, Commerce \& Administration $\quad 0.37$

HVE, n.e.c. $\quad 0.33$ 
IVE, Engineering 0.33

IVE, Commerce \& Administration 0.32

Lower Technician Multiple qualifications

Higher General Secondary Education $\quad 0.72$

IVE, Administrative, legal \& fiscal $\quad 0.72$

IVE, Social \& Cultural $\quad 0.68$

Lower General Secondary Education $\quad 0.66$

HVE, Administrative, Legal \& Fiscal $\quad 0.64$ 